\title{
ZUSAS
}

seience for a changing world

\section{PETROLEUM SYSTEMS OF THE NORTHWEST JAVA PROVINCE, JAVA AND OFFSHORE SOUTHEAST SUMATRA, INDONESIA}

by Michele G. Bishop ${ }^{1}$

Open-File Report 99-50R

2000

This report is preliminary and has not been reviewed for conformity with the U. S. Geological Survey editorial standards or with the North American Stratigraphic Code. Any use of trade names is for descriptive purposes only and does not imply endorsement by the U. S. government.

\section{U. S. Department of the Interior U.S. Geological Survey}

${ }^{1}$ Consultant, Wyoming PG-783, contracted to U. S. Geological Survey, Denver, Colorado 


\section{FOREWORD}

This report was prepared as part of the World Energy Project of the U.S. Geological Survey. For this project, the world was divided into 8 regions and 937 geologic provinces, which were then ranked according to the discovered oil and gas volumes within each (Klett and others, 1997). Then, 76 "priority" provinces (exclusive of the U.S. and chosen for their high ranking) and 26 "boutique" provinces (exclusive of the U.S. and chosen for their anticipated petroleum richness or special regional economic importance) were selected for appraisal of oil and gas resources. The petroleum geology of these priority and boutique provinces is described in this series of reports.

The purpose of the World Energy Project is to assess the quantities of oil, gas, and natural gas liquids that have the potential to be added to reserves within the next 30 years. These volumes either reside in undiscovered fields whose sizes exceed the stated minimumfield-size cutoff value for the assessment unit (variable, but must be at least 1 million barrels of oil equivalent) or occur as reserve growth of fields already discovered.

The total petroleum system constitutes the basic geologic unit of the oil and gas assessment. The total petroleum system includes all genetically related petroleum that occurs in shows and accumulations (discovered and undiscovered) that (1) has been generated by a pod or by closely related pods of mature source rock, and (2) exists within a limited mappable geologic space, along with the other essential mappable geologic elements (reservoir, seal, and overburden rocks) that control the fundamental processes of generation, expulsion, migration, entrapment, and preservation of petroleum. The minimum petroleum system is that part of a total petroleum system encompassing discovered shows and accumulations along with the geologic space in which the various essential elements have been proved by these discoveries.

An assessment unit is a mappable part of a total petroleum system in which discovered and undiscovered fields constitute a single relatively homogenous population such that the chosen methodology of resource assessment based on estimation of the number and sizes of undiscovered fields is applicable. A total petroleum system might equate to a single assessment unit, or it may be subdivided into two or more assessment units if each assessment unit is sufficiently homogeneous in terms of geology, exploration considerations, and risk to assess individually.

A graphical depiction of the elements of a total petroleum system is provided in the form of an event chart that shows the times of (1) deposition of essential rock units; (2) trap formation; (3) generation, migration, and accumulation of hydrocarbons; and (4) preservation of hydrocarbons.

A numeric code identifies each region, province, total petroleum system, and assessment unit; these codes are uniform throughout the project and will identify the same type of entity in any of the publications. The code is as follows: 
Region, single digit

Example

Province, three digits to the right of region code

3

3162

Total Petroleum System, two digits to the right of province code

316205

Assessment unit, two digits to the right of petroleum system code

31620504

The codes for the regions and provinces are listed in Klett and others, 1997.

Oil and gas reserves quoted in this report are derived from Petroconsultants' Petroleum Exploration and Production database (Petroconsultants, 1996) and other area reports from Petroconsultants, Inc., unless otherwise noted.

Fields, for the purpose of this report, include producing fields, discoveries (suspended and abandoned) and shows as defined by Petroconsultants (1996) and may consist of a single well with no production.

Figure(s) in this report that show boundaries of the total petroleum system(s), assessment units, and pods of active source rocks were compiled using geographic information system (GIS) software. Political boundaries and cartographic representations were taken, with permission, from Environmental Systems Research Institute's ArcWorld 1:3 million digital coverage (1992), have no political significance, and are displayed for general reference only. Oil and gas field centerpoints, shown on this (these) figure(s), are reproduced, with permission, from Petroconsultants, 1996.

\section{REFERENCES}

Environmental Systems Research Institute Inc., 1992, ArcWorld 1:3M digital database: Environmental Systems Research Institute, Inc. (ESRI), available from ESRI, Redlands, CA, scale: 1:3,000,000.

Klett, T.R., Ahlbrandt, T. A., Schmoker, J.W., and Dolton, G. L., 1997, Ranking of the world's oil and gas provinces by known petroleum volumes: U.S. Geological Survey Open-File Report 97-463, one CD-ROM.

Petroconsultants, 1996, Petroleum Exploration and Production Database: Petroconsultants, Inc., P.O. Box 740619, 6600 Sands Point Drive, Houston TX 77274-0619, USA or Petroconsultants, Inc., P.O. Box 152, 24 Chemin de la Mairie, 1258 Perly, Geneva, Switzerland. 


\section{ABSTRACT}

Mature, synrift lacustrine shales of Eocene to Oligocene age and mature, late-rift coals and coaly shales of Oligocene to Miocene age are source rocks for oil and gas in two important petroleum systems of the onshore and offshore areas of the Northwest Java Basin. Biogenic gas and carbonate-sourced gas have also been identified. These hydrocarbons are trapped primarily in anticlines and fault blocks involving sandstone and carbonate reservoirs. These source rocks and reservoir rocks were deposited in a complex of Tertiary rift basins formed from single or multiple half-grabens on the south edge of the Sunda Shelf plate. The overall transgressive succession was punctuated by clastic input from the exposed Sunda Shelf and marine transgressions from the south. The Northwest Java province may contain more than 2 billion barrels of oil equivalent in addition to the 10 billion barrels of oil equivalent already identified.

\section{INTRODUCTION}

The Northwest Java Basin Province \#3824 consists of sediment-filled, half-graben basins formed on the southern edge of the Sunda Shelf plate or craton during the Tertiary. Two important petroleum systems are identified: (1) Banuwati-Oligocene/Miocene (382401) with assessment unit Sunda/Asri (38240101); and (2) Jatibarang/Talang AkarOligocene/Miocene (382402) with assessment unit Ardjuna (38240201). There are also two other proposed petroleum systems, Tertiary-Parigi (382403) with a Biogenic Gas assessment unit (38240301) and Tertiary-Cenozoic (382404) with the Billiton Basin Hypothetical assessment unit (38240401) (Fig. 1).

The U.S. Geological Survey assessment of the estimated quantities of conventional oil, gas and condensate that have the potential to be added to reserves by the year 2025 for this province is 2.008 billion barrels of oil equivalent (BBOE); 658 million barrels of oil (MMBO), 7,453 billion cubic feet of gas (BCFG), and 108 million barrels of natural gas liquids (MMBNGL) (U.S. Geological Survey World Energy Assessment Team, 2000). The combined known reserves, grown reserves, and assessed new resources are more than $12 \mathrm{BBOE}$ for this province (U.S. Geological Survey World Energy Assessment Team, 2000). Other estimates for the region are 4 BBOE recoverable with approximately 14 BBOE in place (Noble and others, 1997).

The Banuwati-Oligocene/Miocene petroleum system is located offshore Sumatra. The source-rock facies consists of, lacustrine, oil-prone Banuwati shales of Eocene to Oligocene age, that were deposited as the initial fill in half-graben rift basins.

The second petroleum system, Jatibarang/Talang Akar-Oligocene/Miocene, is located onshore and offshore northwest Java. It is sourced from lacustrine shales interbedded with volcanics of the Eocene to lower Oligocene Jatibarang Formation combined with thick, oil- and gas-prone coals of the upper Oligocene to Miocene upper Talang Akar Formation. These coal-bearing, fluvial deltaic sediments were deposited in a late rift and post-rift sag phase. Lower Talang Akar Formation oil-prone shales that formed in shallow lakes may also have contributed hydrocarbons to this petroleum system.

Reservoir facies for both the Banuwati-Oligocene/Miocene, and Jatibarang/Talang Akar-Oligocene/Miocene systems include Oligocene through Miocene synrift lacustrine fans and fluvial clastics, late and post-rift sag-phase fluvial, shoreline, 
deltaic clastics and marine carbonate reefs and bioherms.

A third petroleum system, Tertiary-Parigi, is located in an area north of Jakarta to onshore and offshore near Semarang (Haposan and others, 1997; Noble and others, 1997). This system consists of carbonate-sourced and bacterial gas primarily in carbonate reservoirs of late Miocene to Pliocene age. Offshore north of the Seribu Platform, reservoir rocks are marine shelf deposits of the late Miocene to Pliocene Parigi and Cisubuh Formations and are carbonates of the Parigi Formation near Semarang (Fig. 1). A fourth hypothetical petroleum system, Tertiary-Cenozoic, is comprised of the Vera and Billiton Basins and extends northeast into the Java Sea where sediments reach a reported thickness of about 6,500 ft (2,000 m) (Fig. 1) (Hamilton, 1974). A few structures have been drilled with no reported shows (Petroconsultants, 1996). The possibility of source rock and maturity are not well known although the section is sufficiently thick for source rocks to be mature.

\section{PROVINCE GEOLOGY}

The Northwest Java Basin Province 3824 lies mainly in the waters of Indonesia and includes some onshore areas of Java (Fig. 1). The province includes the basins of Sunda and Asri in the offshore southeastern Sumatra region and extends eastward across the Java Sea to the Ardjuna Basin region and Jatibarang Basin and to near the town of Semarang on the north coast of Java (Figs. 1 and 2). The southern boundary of the province is onshore Java at the northern margin of the Bogor Trough. The province also includes the offshore Vera Basin and portions of Billiton Basin, Karimunjawa Arch, and Banwean Trough, all of which are on the Sunda Shelf under the Java Sea (Fig. 2).

Onshore concessions are operated by Pertamina, the Indonesian national oil company, and offshore concessions are operated by companies in production-sharing agreements with Pertamina. Concessions cover large areas and have been operated for many years; however, some parts of the Java Sea region remain virtually unexplored.

\section{Tectonics}

The Sunda Shelf plate is confined on the east by oceanic crust and spreading centers, to the west by continental crust, and to the south by Cretaceous oceanic and continental crust and was emergent during much of the Tertiary (Pulunggono, 1985; Ponto and others, 1988). Since the early Tertiary, the plate has generally tilted southward and subsided (Ponto and others, 1988). The current subduction system, located offshore south of present-day Java, began in late Oligocene (Hamilton, 1979). Tectonic stress and extension, resulting from northward movement of the Australian and Indian plates and rotation of Borneo, formed rifts or half-graben complexes along much of the southern margin of the Sunda Shelf plate (now Sumatra and Java) in Eocene to Oligocene time (Fig. 3) (Hall, 1997a, b; Longley, 1997; Sudarmono and others, 1997). These complexes are aligned north-south and are separated by faulted plateaus. Onshore structural features comprise alternating basins and structural highs, from west to east these are the Tangerang High, Ciputat Basin, Rengasdengklok High, Pasir Putih Basin, PamanukanKandanghaur High and Horst, Jatibarang Basin, and the Ceribon Trough (Fig. 2) (Reminton and Pranyoto, 1985; Adnan and others, 1991). Offshore structures include the Sunda and Asri Basins, Seribu Platform, Ardjuna Basin, F High, Vera Basin, Jatibarang 
Basin, Eastern Shelf, Billiton Basin, Karimunjawa Arch, and the Banwean Trough (Ponto and others, 1988; Adnan and others, 1991). Some evidence suggests a combined symmetrical sag and half-graben history to the early tectonics of the Sunda and Asri Basins (Aldrich and others, 1995).

\section{Deposition}

Half-graben style deposits began to fill individual and connected basins beginning with locally derived clastics from the shoulders of the half-grabens, some of which were sometimes occupied by fresh-water lakes (Fig. 4) (Bishop, 1988; Wicaksono and others, 1992). Sediments eroded from the emergent Sunda Shelf entered the rift basins generally from the north. Regionally derived clastic sediments were added to the half-grabens as subsidence continued, and larger basins developed, changing to the late-rift and post-rift sag phase (Wicaksono and others, 1992). Lacustrine source rocks, reservoir facies, and migration paths described in the Sunda and Asri Basins are analogous to the distinct and predictable sedimentary facies associated with half-graben architecture described by Bishop (1988); Lambiase (1990); and Lambiase and Bosworth (1995).

Clastics from the Sunda highlands formed shoreline and deltaic deposits that surrounded and filled the half-graben lacustrine basins (Ponto and others, 1988; Sudarmono and others, 1997). Regional minor marine transgressions of late Oligocene age from the south, influenced the southernmost of these basins individually at differing times (Sudarmono and others, 1997). The associated marine shorelines, which were roughly parallel with the present-day north coast, generally shifted north and south with changes in relative sea level (Ponto and others, 1988). The relatively high areas of the Eastern Shelf and the Seribu Platform were separated by the subsiding Ardjuna Basin, where late Oligocene age deltaic and marine deposits accumulated (Ponto and others, 1988). In the Ardjuna Basin area, south across Java and the Jatibarang area, thick coal deposits developed (Gordon, 1985; Ponto and others, 1988). Shallow marine facies of latest Oligocene and earliest Miocene age are also shown to occur in the Vera Basin, separated from, and later connected to, the Ardjuna Basin (Ponto and others, 1988). During early Miocene time, a marine transgression from the south flooded much of the south Sunda Shelf including all of the Northwest Java Province. The transgression occurred latest in the Asri Basin (Aldrich and others, 1995). Marine carbonates formed around paleohighs (Park and others, 1995). High fault-block trends of the half-graben systems, aligned north-south, also were the sites of carbonate buildups that reinforced the north-south alignment well after the fault blocks were buried. Intermittent lowstands exposed the reefs and associated facies producing areas of enhanced porosity for the development of later hydrocarbon reservoirs (Park and others, 1995; Wicaksono and others, 1995; Pertamina, 1996). Widespread marine highstands in the Miocene deposited marine shales and marls that are considered to provide basin and regional hydrocarbon seals (Wicaksono and others, 1995; Pertamina, 1996). Major regression in the middle Miocene resulted in the deposition of clastic shallow marine, shoreline, deltaic, and continental deposits alternating with the occasional phases of carbonate development (Pertamina, 1996). Late Miocene transgressions again provided for development of carbonate bioherms and deposition of marine sediments (Pertamina, 1996). During the Pleistocene, the Sunda Shelf was exposed intermittently, and shales, fluvial clastics, and 
volcanics were deposited (Pertamina, 1996).

\section{HISTORY OF EXPLORATION}

Knowledge of oil on Java and Sumatra was reported as early as the year 954 and in 1596 a Dutch voyage reported a well in Sumatra producing a balm used for treating rheumatism and for lighting purposes (Van Bemmelen, 1949). In 1869, Von Baumhauer recorded 44 oil seeps in Java, drilling for oil started in West Java in 1872 and the first oil company started operations in East Java in 1887 (Van Bemmelen, 1949).

Early exploration wells in West Java onshore were drilled by Jon Reesink who was a store keeper in Cirebon (Courteney and others, 1989). He visited the United States, collected drilling equipment and skills, and began drilling at Cibodas in 1871 with the financial backing of Nederlandsche Handel Maatschappij (the predecessor of Royal Dutch Shell) (Courteney and others, 1989). Sub-commercial oil was found in two of his first four wells, which were drilled using water buffalo for power. He resumed drilling in 1874 with steam equipment, but the next 5 wells were unsuccessful, which discouraged his backers. However, other drilling ventures were conducted with encouraging shows, and the first commercial oil field was discovered at Randegan in 1939 (Courteney and others, 1989).

Exploration was interrupted until 1967 when, at Jatibarang-44, a major oil field was discovered with reserves in the Jatibarang Volcanics (Courteney and others, 1989). Independent Indonesia American Petroleum Company (IIAPCO) was then formed and negotiations began with Indonesia for the first offshore Production Sharing Contract (Courteney and others, 1989; Wight and others, 1997). Sinclair and Natomas joined IIAPCO in 1966 and drilling began in 1968. The "B" field, with cumulative production of $122 \mathrm{MMBO}$ to 1989 , and the "E" field, with cumulative production of $160 \mathrm{MMBO}$ to 1989, were the first fields in the Ardjuna Basin (Courteney and others, 1989). The Main and Massive reservoirs of Miocene age contain most of the reserves. Light (36-37 $\mathrm{API}$ gravity), low-sulfur, paraffinic and waxy crude with low pour point is produced primarily under water drive (Courteney and others, 1989).

In the Sunda Basin, IIAPCO discovered Cinta field in 1969 (Fig. 5). Production is from the Talang Akar sandstones under strong water drive (Courteney and others, 1989). Over $170 \mathrm{MMBO}$ were produced to 1989 . The Rama and Krisna fields were discovered in the late 1970's and produce from Batu Raja carbonates (Fig. 4) (Courteney and others, 1989; Park and others, 1995). The first discovery in the Asri Basin, the Widuri oil field, was discovered in 1988 (Young and others, 1991).

A subbasin of mature source rock, the North Seribu Trough located east of the Sunda Basin, is a more recently identified exploration target (Pramono and others, 1990).

\section{BANUWATI-OLIGOCENE/MIOCENE (382401) TOTAL PETROLEUM SYSTEM SUNDA / ASRI ASSESSMENT UNIT (38240101)}

Petroleum Occurrence

The Sunda/Asri assessment unit consists of two offshore basins, the Sunda basin that includes several half grabens and the Asri basin that is made up of one half-graben (Figs. 1, 2 and 5). These basins have been combined in petroleum system 382401 
because of the lacustrine nature of the source rocks in both, although each basin has a somewhat different structural style, depositional history, and age. The concession area that includes these basins is just over $11,000 \mathrm{~km}^{2}$ (Wight and others, 1997) and water depth is from 70 - $90 \mathrm{ft}(21-27 \mathrm{~m})$ (Wicaksono and others 1992). As of 1997, cumulative production from these two areas was $800 \mathrm{MMBO}$ at an average rate of 90,000 barrels of oil per day (BOPD) (Wight and others, 1997).

Eleven dry holes were drilled in the Asri Basin before the Widuri-1 well, drilled in 1988, encountered a net oil column of $170 \mathrm{ft}(51 \mathrm{~m})$ in the upper Talang Akar Formation sandstone at $-3,735 \mathrm{ft}(-1135 \mathrm{~m})$ subsea (Young and others 1991). Production of high pour point, low sulfur, 31 ${ }^{\circ}$ API gravity oil from Widuri began in 1990 (Fig. 5) (Young and others, 1991). Reserves were estimated in 1997 at 260 MMBO from six sandstone reservoirs (Wight and others, 1997).

The Sunda Basin has been in production for 25 years with approximately $74 \%$ of the oil of the Sunda Basin produced from Oligocene late synrift sandstone reservoirs of the Talang Akar Formation (Fig. 4). Approximately a quarter of the hydrocarbons, $26 \%$, are produced from Batu Raja reef carbonate reservoirs (Petroconsultants, 1996; Wight and others, 1997). The oils are $22-38^{\circ}$ API gravity, low sulfur, low asphaltenes, high wax, paraffinic crudes (Wicaksono and others, 1992; Pertamina, 1996; Noble and others, 1997). The oils show pronounced similarities in a cross plot of stable carbon isotope composition of the saturate hydrocarbon fraction (13Cs) plotted against the pristine to phytane ratio $(\mathrm{Pr} / \mathrm{Ph})$ and source rocks are interpreted to be predominantly lacustrine shales (Fig. 6) (GeoMark, 1998). Variations occur that are attributed to lateral facies changes in the amount of terrestrial material in the source rock (Wicaksono and others, 1995). Gas found in middle Miocene and older reservoirs is associated with oil or is derived from oil (Noble and others, 1997). Carbon dioxide content is generally below 5\% (Noble and others, 1997).

Vertical migration is suggested as the mechanism to fill reservoirs over the limited areal extent of mature source rock, and both vertical and lateral migration are probably involved in the sourcing of reservoirs located updip and away from the areas of mature source rock (Wicaksono and others, 1992). Lateral migration took place through several zones of sandstone and weathered basement conduits. The pre-Tertiary basement rocks at Ambar (Fig. 5) form a hydrocarbon reservoir as much as $200 \mathrm{ft}(60 \mathrm{~m})$ thick (Pertamina, 1996). This zone of weathered basement rocks is also thought to provide an important path for hydrocarbons generated in the half-graben to migrate updip into younger reservoirs (Pertamina, 1996).

The Widuri Field in the Asri Basin (Fig. 5) is bounded by a fault that trapped petroleum, generated by mature Banuwati source rock in the deep half graben, migrating up-dip along the shoaling margin of the Asri half graben. The occurrence of this field indicates lateral migration of over 18 miles $(30 \mathrm{~km})$ (Wicaksono and others, 1992).

Considerable lateral migration is also suggested in the Sunda Basin by the locations of numerous accumulations away from known locations of mature source rock (Fig. 5). In the southeastern part of this basin there is oil production from shallow marine and carbonate platform limestones in the lower Miocene Batu Raja Formation and Gumai Formation (Wicaksono and others, 1995). Although seven fields in this combined carbonate play have produced $250 \mathrm{MMBO}$, poor reservoir quality, limited trap size, and low recovery factors have limited the success of discoveries in this play (Wicaksono and 
others, 1995). Fields that produce oil and gas from carbonate reservoirs in the Sunda Basin are distributed as far north as Dita Field and are generally located on the western and southern edges of the Sunda Basin (Park and others, 1995). Migration from the mature Banuwati shales was initially upward out of the main half-graben along faults and laterally as much as 28 miles $(45 \mathrm{~km}$ ) into these carbonate reservoir traps (Wicaksono and others, 1995).

\section{Source Rock and Maturation}

Late Eocene to early Oligocene Banuwati lacustrine shale in the Sunda and Asri Basins was deposited in anoxic, lake environments (Fig. 4) (Wicaksono and others, 1992; Pertamina, 1996; Noble and others, 1997). This shale represents the greatest extent of the lakes late in the period of Banuwati Formation deposition. These lakes occupied several contemporaneous half-graben and connected half-graben systems throughout the province. Two eastward tilted and one westward tilted half-grabens were depocenters for the Banuwati Shale in the Sunda Basin where basement is 12,000 - 16,000 $\mathrm{ft}(3,648$ 4,864 m) deep (Wicaksono and others, 1992). One eastward tilted half-graben was the site of deposition of the Banuwati Shale in the Asri Basin (Wicaksono and others, 1995). This dark brown to black shale is more than $400 \mathrm{ft}(121 \mathrm{~m})$ thick in the deepest part of the Sunda Basin half-graben, but thins to $100 \mathrm{ft}(30 \mathrm{~m})$ at the shoaling margin (Wicaksono and others, 1992; Pertamina, 1996). This shale is an oil-prone (Type I) source rock and seal for intraformational sandstones (Wicaksono and others, 1992). The lacustrine source-rock shales have total organic carbon (TOC) values of 1.87-8.0 wt $\%$, and hydrogen index (HI) of 573-637 milligrams hydrocarbon/gram TOC (mg HC/g) (Pertamina, 1996). Modeling suggests that these oil-prone source rocks reached the main phase of oil generation when buried at depths between 9,500 ft (2,888 m) (Wicaksono and others, 1992) and $11,800 \mathrm{ft}(3,587 \mathrm{~m})$ (Pertamina, 1996) from 15-8 MA. Discoveries of 1.2 billion barrels of oil (BBO) recoverable and $65 \mathrm{BCFG}$ are attributed to this source rock (Aldrich and others, 1995).

Coals and overbank shales and shallow lacustrine shales of the Zelda and Gita Members of the Talang Akar Formation would be good source rocks if mature. The Gita coals are thick with TOC values of 3.7-25 wt\% (Pertamina, 1996). Marine shales and marls of the Batu Raja and Gumai Formations might generate hydrocarbons if buried deeply enough to be mature (Pertamina, 1996).

\section{Traps}

Five of the six fields described by Petroconsultants (1996) in the Asri Basin are trapped in anticlines; the largest field, Widuri, is described as a fault trap. More than $55 \%$ of the fields in the Sunda Basin are fault or structural traps (Petroconsultants, 1996). Almost $63 \%$ of the oil equivalent reserves in the assessment unit are trapped by faults, fault blocks, or other structural settings, whereas more than $36 \%$ of the reserves are trapped in anticlines (Petroconsultants, 1996). Carbonate reefs and buildups account for the remainder, which is mainly gas (Petroconsultants, 1996).

\section{Reservoir Rocks}


The Oligocene Talang Akar Formation, including the Zelda and Gita sandstones, is the most important hydrocarbon reservoir in the Sunda and Asri Basins, containing more than $80 \%$ of the oil equivalent reserves in the assessment unit (Fig. 4) (Petroconsultants, 1996).

Banuwati Formation

The Banuwati Formation, of Eocene to Oligocene age, is primarily a source rock but sandstone reservoirs are present beneath and within the source rock interval (Fig. 4). These synrift, coarse clastic deposits represent early rift-fill alluvial and fluvial environments and later marginal-lacustrine, fluvial, deltaic, and turbidite settings (Aldrich and others, 1995; Pertamina, 1996). The Sunda Basin Janti and Yani fans prograded into deep water where lacustrine source-rock facies were being deposited. These fans resulted in sandstone reservoirs with 5-15\% porosity in sections as much as $700 \mathrm{ft}(212 \mathrm{~m})$ thick (Pertamina, 1996). The Janti-3 well IP at 2,450 BOPD and Yani-1 and -2 wells at 1,000 BOPD and 100 BOPD (Fig. 5) (Pertamina, 1996). Porosity is reduced due to compaction and cementation but secondary solution porosity occurs. Similar fan deposits might be expected in the Asri Basin and other half-grabens.

Talang Akar Formation

The Talang Akar Formation in the Sunda/Asri area is divided into the Oligocene Zelda Member and the Miocene Gita Member (Fig. 4). In the Asri Basin the Gita Member is coeval with the lower Batu Raja Formation.

Stacked sandstones of braided stream, distributary, and point bar facies show an overall coarsening-upward trend from discrete fluvial channels in the lower part of the Zelda Member to amalgamated channels in the upper part (Pertamina, 1996). The channels range from 5-25 ft (1.5-6 m) thick with 20-30\% porosity and several Darcies of permeability (Pertamina, 1996). The Zelda Member is a producing reservoir and also serves as a migration conduit for the underlying Banuwati Formation lacustrine source to overlying Batu Raja carbonate reservoirs (Aldrich and others, 1995; Pertamina, 1996). Diagenetic kaolinite occludes pore throats at increased burial depths below 8,000 ft $(2,432 \mathrm{~m})$ (Pertamina, 1996). Risma-1,2,3 produce oil from this interval and IP at 1,2454,500 BOPD (Fig. 5) (Pertamina, 1996).

The Gita Member in the Asri Basin is younger than the Gita in the Sunda Basin to the south, the marine transgression having occurred later toward the north. It is the primary reservoir at Widuri and Intan fields in Asri Basin with $60 \%$ of the field's reserves (Fig. 5) (Petroconsultants, 1996). The Asri Basin was tested in 1988 and Widuri-1, drilled to $-3,735 \mathrm{ft}$ subsea $(1,135 \mathrm{~m})$, found $170 \mathrm{ft}(51 \mathrm{~m})$ of net oil in the upper Talang Akar Formation in 6 stacked reservoirs (Young and others, 1991). Delineation drilling confirmed an oil field of approximately 5,000 acres (2,020 hectares) (Young and others, 1991). Production began in 1990. The field is a combination structural and stratigraphic trap considered a three-way fault closure (Young and others, 1996). The fault is an Oligocene fault reactivated in early Miocene time (Young and others, 1991). The Gita Member in the Asri Basin consists of distributary channel sands as much as 56 $\mathrm{ft}(17 \mathrm{~m})$ thick in channels 2,000-4,000 ft (608-1,216 m) wide (Pertamina, 1996). Porosity is $25-35 \%$, permeability is $1-30$ Darcies and IP is $2,000-6,000$ BOPD 
(Pertamina, 1996). The entire section generally fines upward and becomes increasingly marine.

\section{Lower Batu Raja Formation}

The Lower Batu Raja carbonates were developed over a paleotopography of hills and incised valleys in a shallow shelf setting (Fig. 4) (Park and others, 1995). A series of Batu Raja Formation reefs and lagoonal carbonates fringe pre-Tertiary igneous and volcanic islands (Wight and Hardian, 1982). The Cinta-Rama complex of fields is located around the Cinta Arch and the Krisna and Yvonne Fields rim paleohighs (Fig. 5) (Park and others, 1995). The Krisna oil field, discovered in 1976, is located at the Krisna high, the largest of these paleoislands (Figs. 3 and 5) (Wight and Hardian, 1982). The Batu Raja is absent on the crest of the Krisna high and thickens away from the high to a maximum of $250 \mathrm{ft}(76 \mathrm{~m})$ (Wight and Hardian, 1982). Some reservoirs within this unit exceed $100 \mathrm{ft}(30 \mathrm{~m})$ in thickness and 25\% average porosity (Wight and Hardian, 1982). IPs in wells with net pay of 40-100 ft $(12-30 \mathrm{~m})$ were measured at 3,000-8,000 BOPD with water drive (Wight and Hardian, 1982). The oil/water contact is $150 \mathrm{ft}$ (45 m) lower on the northern side of the field (Wight and Hardian, 1982). High secondary porosity was developed in reef facies and ordinarily tight lagoonal facies due to leaching of aragonitic skeletal material in freshwater phreatic environments as a result of repeated lowstand subaerial exposure (Wight and Hardian, 1982). Fracturing and basement weathering zones add to permeability and the development of migration pathways (Wight and Hardian, 1982).

In the southeastern portion of the Sunda Basin, the Lower Batu Raja Formation unconformably overlies shales and coals of the Gita Member of the Talang Akar Formation (Wicaksono and others, 1995). The $240 \mathrm{ft}(73 \mathrm{~m})$ thick section is composed of four cycles of varying thickness that represent development in $65 \mathrm{ft}(20 \mathrm{~m})$ water depths to subaerial conditions (Wicaksono and others, 1995). Porosity was enhanced by meteoric dissolution but subsequently infilled by calcite cement, resulting in generally poor porosity (Wicaksono and others, 1995). Porosity ranges from 5-35\% with permeability less than $10 \mathrm{mD}$ and mostly less than $1 \mathrm{mD}$ (Wicaksono and others, 1995). Carbonates of the Lower and Upper Batu Raja and the Gumai Limestone in this location were developed on a north plunging platform that was alternately flooded and exposed (Wicaksono and others, 1995).

\section{Upper Batu Raja Formation}

In the southeastern Sunda Basin the Upper Batu Raja consists of limestones more than $200 \mathrm{ft}(61 \mathrm{~m})$ thick developed during a highstand on a shallow, interior platform where water circulation was restricted (Wicaksono and others, 1995). In Nora and Yuli wells the Upper Batu Raja consists of six $20-40 \mathrm{ft}$ (6-12 m) thick sequences of wackestones changing to overlying packstones and rudstones with branching coral debris and decreasing clay content (Wicaksono and others, 1995). The upper section of each sequence displays increased porosity. Minor to major subaerial exposure is indicated at the top of each sequence and vadose diagenetic features appear at the top of the member at the contact with the overlying Gumai Formation (Wicaksono and others, 1995). Secondary porosity of $20-30 \%$ is a result of aragonite dissolution produced by repeated exposure and calcite cement dissolution from major exposure at the end of the early 
Miocene (Wicaksono and others, 1995). Permeabilities are generally $<10 \mathrm{mD}$ with local areas of $100 \mathrm{mD}$ (Wicaksono and others, 1995). Initial production (IP) following acidization of Nora- 1 was reported at 2,275 BOPD (Wicaksono and others, 1995).

In the Asri Basin, the Upper Batu Raja consists of thin, shallow marine shales and poorly developed limestone and sandstone with some non-commercial shows of oil and gas.

\section{Gumai Formation}

The lower Miocene Gumai Formation in the Sunda Basin represents a period of transgression ending with deposition of a regional shale seal (Fig. 4) (Wicaksono and others, 1995). The Gumai Limestone Member is present as localized carbonate buildups in the southeastern area of the basin. It is composed of four cycles of deep to shallow marine rocks, only the oldest of which shows evidence of subsequent subaerial exposure (Wicaksono and others, 1995). Wicaksono and others (1995) describe an extensive dissolution phase caused by flushing of the carbonate platform with meteoric water before the end of carbonate deposition.

Seals

The Gumai Shale Member is an effective regional seal in the Sunda/Asri area (Pertamina, 1996) overlying both the Batu Raja Formation and the Gumai Limestone Member in the southeastern area of the Sunda Basin (Wicaksono and others, 1995). It is described as a deep-water transgressive claystone (Wicaksono and others, 1995) and is as much as $900 \mathrm{ft}$ (274 m) thick (Pertamina, 1996). Clayey sediments continued to be deposited during middle Miocene, and strata of this age are known as the Air Benakat claystone (Fig. 4). The claystones seal Batu Raja reservoirs that developed on the carbonate platform and carbonate buildups that developed on and around paleohighs (Fig. 4) (Wicaksono and others, 1992). The Krisna Field is sealed by Batu Raja shale, which drapes the carbonate reservoir and onlaps basement (Wight and Hardian, 1982). In the Asri Basin, the Gumai is present generally as shale without the carbonate component (Wicaksono and others, 1995; Aldrich and others, 1995). Within the basin, the shales of the Batu Raja Formation form seals (Wicaksono and others, 1992), and shales at the top of the Talang Akar Formation seal clastic reservoirs (Wight and others, 1997). The Gumai is overlain by the Cisubuh Formation, which in some places consists of alluvial sandstone and volcanics of late Miocene-Plio-Pleistocene age and in other places is a marine shale of Miocene to Pliocene age (Fig. 4) (Pertamina, 1996). The Cisubuh locally acts as a seal where the Gumai shale is either absent or has been transected by faults (Pertamina, 1996).

\section{JATIBARANG/TALANG AKAR-OLIGOCENE/MIOCENE (382402) ARDJUNA ASSESSMENT UNIT (38240201)}

\section{Petroleum Occurrence}

The Jatibarang/Talang Akar-Oligocene/Miocene petroleum system consists of several pods of active Jatibarang and Talang Akar Formation source rocks (Fig. 7). The 
areas are combined into one petroleum system and one assessment unit in this report, although geochemical distinctions can be made among hydrocarbons derived from these mature areas of the same source-rock interval (Noble and others, 1997). There are five major stratigraphic intervals that produce hydrocarbons in the Ardjuna assessment unit each with associated trap types: 1) Jatibarang tuff, 2) Talang Akar sandstones, 3) Batu Raja carbonates, 4) Upper Cibulakan clastics and carbonates, and 5) Parigi carbonates (Fig. 4). Some of these stratigraphic intervals form geographic trends; the marine carbonate reefs, for example, are located on topographic highs (frequently north/south trending fault blocks) and occupy areas of favorable paleowater depth.

The oldest producing stratigraphic horizon is volcanic tuff of the Jatibarang Formation. Hydrocarbons accumulated in fault blocks adjacent to downfaulted areas of mature source rock primarily in the Jatibarang Basin near Cirebon (Fig. 8) (Adnan and others, 1991). The Jatibarang field had produced 72 MMBO by 1989 from the volcanic reservoirs. Additional reserves are in overlying reservoirs (Adnan and others, 1991), with production from Talang Akar clastics, Batu Raja carbonates, Upper Cibulakan clastics, and Parigi carbonates (Adnan and others, 1991). Lacustrine rocks in the Jatibarang Basin, in both onshore and offshore areas, are the source of large hydrocarbon accumulations in all directions (Adnan and others, 1991; Noble and others, 1997). This mature lacustrine source rock is included in the Jatibarang/Talang Akar-

Oligocene/Miocene petroleum system (382402). Oils identified as sourced by lacustrine source rocks are mixed in some fields and distinct in others in this area (Noble and others, 1997). The Jatibarang field is the largest field discovered in onshore Northwest Java (Adnan and others, 1991).

Sandstone reservoirs of the fluvial-deltaic, shoreline, shallow marine Talang Akar Formation produce oil and gas in traps distributed onshore and offshore in the Ardjuna assessment unit (Fig. 8) (Pertamina, 1996). Marine channel sandstone and reef limestone of the Batu Raja Formation, which formed during the post-rift sag phase as the result of a widespread marine transgression from the south, are also important producing reservoirs in the assessment unit (Pertamina, 1998).

The Upper Cibulakan Massive and Main reservoirs consist of deltaic and nearshore clastics and platform carbonates. They were deposited during a rise in sea level that flooded the Sunda Platform (Yaman and others, 1991). North- to southoriented Mid-Main carbonate buildups are located in a small area northeast of Jakarta (Yaman and others, 1991).

Pre-Parigi and Parigi carbonates were developed in middle to late Miocene time (Fig. 4), when a carbonate platform with north-south oriented bioherms developed across the area (Yaman and others, 1991). Pre-Parigi buildups are located in a large area that extends 30 miles $(50 \mathrm{~km})$ offshore northeast of Jakarta (Carter and Hutabarat, 1994; Yaman and others, 1991). From east of Jakarta to north of Cirebon, Parigi carbonate buildups occur, offset to the east of the Pre-Parigi buildups, over a large area both onshore and offshore (Carter and Hutabarat, 1994; Yaman and others, 1991).

Oils analyzed by GeoMark (1998) from the Ardjuna assessment unit show similarities of stable carbon isotope composition of the saturate hydrocarbon fraction (13Cs) plotted against the pristine to phytane ratio $(\mathrm{Pr} / \mathrm{Ph})$ (Fig. 6). The unit has oils with high oleanane concentrations, $\mathrm{C}_{27} / \mathrm{C}_{29}$ sterane $>1$, hopane/sterane $>4$ and dominated by medium weight $n$-alkanes (Haposan and others, 1997). These oils are attributed to source 
rocks formed in a deltaic, coal-rich depositional environment (Haposan and others, 1997). Sulfur concentrations of $0.02-0.42 \%$ were reported by Haposan and others (1997).

There are also oils that have an abundance of botryococcane, hopane/sterane $>8$, sterane distribution of $\mathrm{C}_{28}$ is $>\mathrm{C}_{29}$ is greater than $\mathrm{C}_{27}$, and $n$-alkanes of $\mathrm{C}_{21}-\mathrm{C}_{33}$ indicating a lacustrine origin for some of the source rocks in the assessment unit (Haposan and others, 1997). Sulfur concentrations of these oils were reported as $0.11-0.16 \%$ (Haposan and others, 1997). These accumulations have been included with the petroleum system. A carbonate-derived oil, possibly mixed with the deltaic/coal sourced oils, was also recognized by Haposan and others (1997).

Gas in the Jatibarang/Talang Akar-Oligocene/Miocene petroleum system, is interpreted to be derived from the gas phase of the same source rocks as discussed above. Carbon dioxide content in gas is low except in some onshore areas where $\mathrm{CO}_{2}$ content is higher than $50 \%$ and attributed to metamorphism of carbonate minerals (Noble and others, 1997).

Petroleum migration occurs both vertically and laterally. Vertical migration paths are primarily faults that allow migration from the source rock to overlying reservoir rocks (Noble and others, 1997). Lateral migration paths occur along basement surfaces and unconformities, or through porous beds, to reservoir rocks distant from the location of the mature source rock. Clastic channels of the Talang Akar Formation, aligned north to south, are believed to be especially important migration paths in the region (Noble and others, 1997). These channels connect the several basins that contain mature source rock onshore to reservoirs that now are located offshore, up dip and to the north (Fig. 1) (Noble and others, 1997). Combinations of vertical and lateral migration are important mechanisms in this region for sourcing multiple stacked reservoirs (Noble and other, 1997). Gas in the shallow carbonate fields of Pre-Parigi and Parigi Formations may be derived from Talang Akar source rocks in as much as many of these buildups occur on faults that controlled subsidence of some of the mature subbasins. Carbonate buildups that lack a fault system, on the other hand, contain little or no gas (Yaman and others, 1991; Carter and Hutabarat, 1994). Other buildups that are located away from these subbasins and faults may contain gas from the biogenic petroleum system and assessment unit.

The average field that produces from the Talang Akar Formation in the offshore area contains 25-30 million barrels of oil equivalent (MMBOE) with equal volumes of gas and oil (Gresko and others, 1995). At the end of 1995 cumulative oil production was reported at $1.025 \mathrm{BBO}$ and gas totaled 1.427 trillion cubic feet of gas (TCFG).

\section{Source Rock and Maturation}

The major source rocks in the Ardjuna assessment unit are deltaic carbonaceous shales and coals in the upper Talang Akar Formation of late Oligocene age that were deposited in a late synrift to post-rift tectonic setting (Noble and others, 1997; Gordon, 1985; Nugrahanto and Noble, 1997; Haposan and others, 1997; Gresko and others, 1995; Ponto and others, 1988). This source rock is type II and III and is oil- and gas-prone with TOC of 40-70 wt\% in the coals and 0.5-9 wt\% in the shales (Ponto and others, 1988), and $\mathrm{HI}$ of 200 - 400. An estimate of expelled hydrocarbon from Talang Akar source rocks is 64 billion barrels (Ponto and others, 1988). Minor source rocks are represented 
by lacustrine strata of the lower Talang Akar Formation (Noble and others, 1997; Nugrahanto and Noble, 1997; Haposan and others, 1997) and possibly from the Jatibarang Formation in the Jatibarang subbasin (Fig. 6) (Gresko and others, 1995; Noble and others, 1997). Hydrocarbon generation may have begun as early as $25 \mathrm{Ma}$ for lower units of the Talang Akar and as late as 1 Ma for later units (Fig. 7) (Pertamina, 1996).

Several grabens with thick sections of Talang Akar Formation are considered to contain mature source rocks (Noble and others, 1997). These subbasins are combined into one petroleum system comprised of coaly, oil-prone source rock, although differences in the oils migrated from these source areas may allow separation into several high-resolution petroleum systems (Noble and others, 1997). The westernmost area of mature source rock is Ciputat where the Talang Akar Formation is thin and mostly marine influenced (Fig. 3) (Noble and others, 1997). Oils in fields to the west and north have been traced to this source rock (Noble and others, 1997). The Kepuh and Pasir Bungur areas of mature source rock contain thick coals of the Talang Akar Formation (Fig. 8) (Noble and others, 1997). Hydrocarbons migrating from these mature areas charge clastic reservoirs of the Talang Akar Formation and carbonate reservoirs of the Mid-Main in both onshore and offshore fields to the north (Figs. 3 and 4) (Noble and others, 1997). Migration of oil from the Cipunegara area of mature Talang Akar source rocks is also primarily to the north to both onshore and offshore fields (Fig. 3) (Noble and others, 1997).

The areas of mature source rock that are located offshore include the South and Central Ardjuna subbasins (Figs. 3 and 8). Seismic data across the Central subbasin indicate fault throws of greater than 3,000 ft $(912 \mathrm{~m})$ at depth and $200 \mathrm{ft}(60 \mathrm{~m})$ in shallow horizons (Carter and Hutabarat, 1994). More than $100 \mathrm{ft}(30 \mathrm{~m})$ of coal source rock occurs in the South subbasin and sources Main and Massive clastic reservoirs and some Talang Akar clastic reservoirs in surrounding fields (Noble and others, 1997). Hydrocarbons generated in the Central subbasin migrate to fields to the south and may have charged as yet undiscovered accumulations to the north (Noble and others, 1997).

Overburden

Transgression during the early Miocene continued as subsidence in the individual and connected basins decreased. Carbonates of the Batu Raja Formation were developed over the Talang Akar source rocks on a shallow carbonate platform and reefs developed on paleohighs (Fig. 4). Mixed clastic and carbonate deposits overlie the Upper Cibulakan Group (Haposan and others, 1997). Biostromal and biohermal limestones of the Parigi Formation were developed across the entire province, followed by deposition of claystone with sandstone, conglomerate, and limestone of the Cisubuh Formation (Haposan and others, 1997). The late Miocene to Plio-Pleistocene Cisubuh Formation coarsens and shallows up representing regression to the south with sediment input from the east and west (Pertamina, 1996).

Traps

Anticlines are the most numerous traps that have been drilled to date in the Ardjuna assessment unit, making up almost $65 \%$ of the fields and containing almost $50 \%$ 
of the oil equivalent reserves (Petroconsultants, 1996). The productive reservoirs in most of these anticlines are sandstones of the Cibulakan Formation although some carbonate reservoirs are involved (Petroconsultants, 1996). Fault blocks and other structural traps account for almost $40 \%$ of the equivalent reserves in the unit (Petroconsultants, 1996).

\section{Reservoir Rocks}

Almost $58 \%$ of the oil and gas in the Ardjuna Basin portion of the assessment unit is from the Main and Massive Formations and $23 \%$ is from the Talang Akar Formation and Batu Raja carbonates (Gresko and others 1995). The oldest reservoir is within a weathered or karstified basement limestone remnant of middle Eocene age (Pertamina, 1996). This reservoir is found in KLS-1 (Fig 7) and is thought to be sourced by rocks in the downdip, deeply buried Talang Akar Formation (Pertamina, 1996).

\section{Jatibarang Formation}

The Eocene to Oligocene synrift Jatibarang Formation is known from the north edge of the Bogor Trough across central Java, east to Bogor and north to Jakarta. This formation is thick in subbasins, being particularly well developed in the Jatibarang subbasin. It probably occurs within the half grabens of the Ardjuna basin, but is thin or missing on structural highs (Gresko and others, 1995). The formation overlies preTertiary basement, which is granite to the northeast and low-grade schist to the northwest (Nutt and Sirait, 1985) and is time equivalent to the Banuwati Shale of the Sunda Basin (Fig. 4) (Pertamina, 1996). The Jatibarang strata in the Jatibarang field area were folded, faulted and eroded prior to deposition of the subsequent Talang Akar Formation (Kalan and others, 1994). This erosional unconformity is recognized in the Ardjuna subbasin (Gresko and others, 1995).

The Jatibarang Formation consists of andesite lavas at the base and dacite basaltic lavas interbedded with clays, sandstone, conglomerate, and pyroclastics in the upper parts (Nutt and Sirait, 1985). Andesitic volcaniclastic flows and tuffs and reworked volcanics and basement-derived sediments have also been described (Pertamina, 1996). Clastic facies change rapidly both vertically and laterally and are mostly fluvial in origin (Adnan and others, 1991). The formation is more than 3,900 ft (1,200 m) thick in the onshore Jatibarang field and thins to the west (Adnan and others, 1991). Depth to the top of the formation ranges from 9,000-13,000 ft (2,700 - 4,000 m) (Pertamina, 1996).

Effective porosity is due to fractures with some intergranular and vessicular porosity (Nutt and Sirait, 1985). Porosity in some of the best producing intervals is as much as $20 \%$ (Kalan and others, 1994) as measured by well logs.

Oil and gas are produced from the Jatibarang Formation in the Jatibarang field (Courteney and others, 1989) and several non-commercial hydrocarbon accumulations have been tested in the offshore area (Pertamina, 1996).

\section{Talang Akar Formation}

The Talang Akar Formation of Oligocene age (Talangakar, Lower Cibulakan Formation) overlies the Jatibarang Formation and basement rocks. The formation is characterized as synrift to late rift continental style deposition (Pertamina, 1996). The lower part represents continental deposition and the upper part represents an increasing 
marine transgression (Gresko and others, 1995; Pertamina, 1996). The formation has also been divided into three units: in ascending order, Talang Akar Grits, Deltaic Talang Akar, and Marine Talang Akar (Kaldi and Atkinson, 1993). The basal unit is generally of poor reservoir quality, the deltaic interval contains both the source rock and good reservoirs, and the marine interval contains good reservoir rocks. For example, the Talang Akar in the Jatibarang Basin area includes carbonaceous shales in the lower unit that contain TOC of $0.5-2.0 \mathrm{wt} \%$ and alternating shales and limestones in the upper unit that produce oil, gas, and condensate (Adnan and others, 1991).

The lower Talang Akar in the Ardjuna area is time equivalent to the Zelda of the Sunda Basin (Fig. 4). It is relatively confined to subbasin areas that had developed during deposition of the Jatibarang Formation (Gresko and others, 1995).

Paleodepositional maps published by Ponto and others (1988) illustrate an eroding Sunda Plate occupied by lake-filled grabens of the Ardjuna area, and an east to west shoreline related to a marine transgression along the Bogor Trough (Suria and others, 1994) that ran from Semarang to Cirebon and on to south of Jakarta during earliest Talang Akar deposition. The lower Talang Akar is dominated by continental deposits, which are immature, fine- to coarse-grained, lithic-rich, and poorly sorted (Gresko and others, 1995; Pertamina, 1996). They consist of sandstones, mudstones, minor coals, and tuffs of alluvial to deltaic origin that total an average thickness of $1,500 \mathrm{ft}(450 \mathrm{~m})$ with local thickness estimated at 2,000 ft (600 m) (Gresko and others, 1995). The sandstone reservoir is mostly poor and highly variable in quality (Gresko and others, 1995; Pertamina, 1996). Carbonate cement reduces porosity along with authigenic kaolinite and compaction of the immature igneous and metasedimentary rock fragments that make up the clastics (Gresko and others, 1995; Pertamina, 1996). Porosity ranges from 7 $28 \%$ with poor permeability (Pertamina, 1996).

The Upper Talang Akar Formation consists of nonmarine to deltaic and marginal marine to shelf sediments deposited during late Oligocene to early Miocene time (Ponto and others, 1988). Paleodepositional maps published by Ponto and others (1988) show the migration of the shoreline toward the north to a position offshore of the modern shoreline between Semarang and Cirebon, and to a later position closer to the modern shoreline between Cirebon and Jakarta during the next stage of deposition. Embayments extended north across the Jatibarang subbasin depositing shoreline facies and across the Ardjuna subbasin where major delta complexes and shoreline facies were deposited (Ponto and others, 1988). The Jatibarang subbasin, Ardjuna subbasin, and the low subsiding area located offshore of the city of Jakarta, continued to be the focus of marine incursion and deposition throughout deposition of the Talang Akar Formation (Ponto and others, 1988).

Reservoir facies that have been identified include estuarine and distributary channels, distributary mouth bars/tidal bars, and delta front bars (Kaldi and Atkinson, 1993; Suria and others, 1994; Pertamina, 1996). The formation may be as much as 1,000 $\mathrm{ft}(300 \mathrm{~m})$ thick, with interbedded shale, limestone, coal, and sandstone in an overall transgressive sequence where flooding surfaces and channel-fill have been identified using seismic data (Suria and others, 1994).

The best reservoir quality is in $40-60 \mathrm{ft}(12-18 \mathrm{~m})$ thick estuarine distributary channel sandstones interpreted as incised valley fill (Pertamina, 1996). These widely distributed, stacked sandstones have porosity of $22-28 \%$ and permeability of $1-3$ 
Darcies (Pertamina, 1996). Sandstones interpreted as delta lobe switching distributary channels are $20-30 \mathrm{ft}(6-12 \mathrm{~m})$ thick, locally cemented by kaolinite, limited in extent, and have 22-28\% porosity (Pertamina, 1996).

Sandstone reservoirs deposited as distributary mouth bars are 3-15 ft $(1-5 \mathrm{~m})$ thick and cemented by quartz overgrowths, illite, and kaolinite (Kaldi and Atkinson, 1993; Pertamina, 1996). Reservoir quality is considered to be good with $21-25 \%$ porosity and $20-526 \mathrm{mD}$ permeability (Pertamina, 1996).

Burrowed delta front sandstones are generally poor reservoirs depending on diagenesis (Kaldi and Atkinson, 1993; Pertamina, 1996). These $1-5 \mathrm{ft}$ (less than $1.5 \mathrm{~m}$ ) thick sandstones are cemented with dolomite and kaolinite resulting in porosity of 6$14 \%$ and permeability of $0.02-0.4 \mathrm{mD}$ (Pertamina, 1996). Wave dominated, delta front sand bars were subjected to early marine ferroan dolomite cementation that reduced porosity to 5\% and resulted in poor quality reservoir sandstones (Pertamina, 1996).

\section{Batu Raja Formation}

As the early Miocene marine transgression continued, and tilting of the Sunda Plate submerged sources of clastics, carbonate development increased in the marine member of the Talang Akar Formation. This formation was eventually conformably overlain by the lower Miocene Batu Raja Formation (Lower Cibulakan Formation) (Ponto and others, 1988).

In the Ardjuna Basin, the Talang Akar Formation consists of well-developed limestones on the Seribu platform, along fault-controlled basement highs, and around basement highs (Pertamina, 1996). The best reservoirs are reef buildups around basement highs that were exposed during sea-level lowstands where secondary moldic porosity resulted from leaching of aragonite grains (Pertamina, 1996). The reefs vary in thickness from $100-150 \mathrm{ft}(30-45 \mathrm{~m})$. The main pay zones are from $5-25 \mathrm{ft}(2-8 \mathrm{~m})$ thick with porosities of $31-36 \%$ and permeabilities of $100-1,000 \mathrm{mD}$ (Pertamina, 1996). In the Jatibarang Basin area, the limestone with shale and marl interbeds of the Batu Raja Formation reaches $165 \mathrm{ft}(50 \mathrm{~m})$ in thickness and produces oil and gas with high $\mathrm{CO}_{2}$ content (Adnan and other, 1991). These rocks contain approximately $5 \%$ of the identified oil equivalent reserves (Petroconsultants, 1996).

\section{Upper Cibulakan Formation}

The lower to middle Miocene Upper Cibulakan Formation was deposited in inner to outer shelf and deltaic environments and is divided into the Massive, Main and PreParigi units. It is equivalent to most of the Gumai Formation and some of the Air Benkat Formation in the Sunda Basin (Fig. 4) (Butterworth and others, 1995; Reksalegora and others, 1996). The Main and Pre-Parigi intervals are major hydrocarbon reservoirs in the Ardjuna assessment unit; sandstone reservoirs contain 58\% of the known oil equivalent reserves with the majority of the reserves in the Main interval (Petroconsultants, 1996). Limestone reservoirs within these intervals contain $10 \%$ of the known reserves (Petroconsultants, 1996).

The Massive and Main intervals of the Upper Cibulakan Formation consist mainly of sandstones and limestones. Deposition was on a marine shelf that occupied the area of the Ardjuna Basin east of the Seribu Platform (Fig. 2) (Purantoro and others, 1994; Reksalegora and others, 1996); marine waters transgressed from the south and 
clastic sediments were derived from the north. The shoreline trended northwest to southeast offshore of the modern coastline (Purantoro and others, 1994; Pertamina, 1996). Multiple sea-level highstands and lowstands have been recognized in this generally transgressive succession (Purantoro and others, 1994).

The Main interval consists of approximately 2,300 ft (700 m) of interbedded shales, sandstones, siltstones, and limestones (Butterworth and others, 1995; Reksalegora and others, 1996). Two distinct sandstone geometries that occur within this interval are discussed by Reksalegora and others (1996): (1) north to south elongate, discrete sandstone bodies, interpreted as filling lowstand erosional features; and (2) extensively distributed cleaning-up sandstones interpreted as shoreface deposits.

The strata interpreted by Purantoro and others (1994) as lowstand sandstones and valley fill within the Main interval are quartzose and highly burrowed. Stacked sandstones are as much as 50-100 ft (165-330 m) thick and are separated by as much as $200 \mathrm{ft}(60 \mathrm{~m})$ of highstand tuffaceous marine shales (Butterworth and others, 1995). These reservoir sandstones have porosity of $16-33 \%$ and permeability of $7-3,000 \mathrm{mD}$ (Purantoro and others, 1994). Strata interpreted as transgressive sandstones are glauconitic and highly burrowed with local calcite cement (Purantoro and others, 1994). The porosity of these reservoir sandstones varies from $21-36 \%$ and permeability ranges from 2-2,000 $\mathrm{mD}$ (Purantoro and others, 1994). Strata interpreted as highstand sandstones are described as calcareous with siderite cement (Purantoro and others, 1994). Reservoir quality is poor to moderate with porosity of $12-30 \%$ and permeability from $0.2-800 \mathrm{mD}$ (Purantoro and others, 1994).

Carbonates in the middle part of the Main interval are north- to south-oriented build-ups on basement highs and on the Seribu Platform (Pertamina, 1996). This interval reaches $340 \mathrm{ft}(100 \mathrm{~m})$ in thickness with secondary solution porosity ranging from 16$32 \%$ in pay zones that are as much as $92 \mathrm{ft}$ thick (28 m) (Pertamina, 1996).

The Pre-Parigi interval of the Upper Cibulakan Formation consists of localized carbonate bioherms formed in middle to late Miocene and distributed over a large area northeast of Jakarta (Yaman and others, 1991; Pertamina, 1996). It is composed of partially dolomitized wackestone to grainstone that grade laterally into claystone with limestone stringers (Pertamina, 1996). In well-developed areas these strata are as much as $700 \mathrm{ft}(210 \mathrm{~m})$ thick, and the bioherms are oriented north to south on shallow marine platforms with structural control of basement highs or prior Batu Raja carbonate buildups (Yaman an others, 1991; Carter and Hutabarat, 1994; Pertamina, 1996). Reservoir quality is excellent, with preserved porosity averaging 30\% and permeability of 2 Darcies (Yaman and others, 1991). The reservoir gas, 98\% methane, is dry; (Yaman and others, 1991).

\section{Parigi Formation}

The late Miocene Parigi Formation developed on structurally stable shallow marine platforms as bioherms associated with paleohighs but not necessarily basement highs (Fig. 4) (Yaman and others, 1991). It is widespread, being distributed onshore and offshore across an area overlapping the eastern portion of Pre-Parigi distribution and continuing to the east (Yaman and others, 1991). Offshore, north- to south-oriented Parigi bioherms are more than $400 \mathrm{ft}$ (120 m) thick (Yaman and others, 1991; Pertamina, 1996). Separated from this trend, to the south in both onshore and offshore areas, are 
northeast- to southwest-oriented Parigi bioherms that are as much as 1,500 $\mathrm{ft}(450 \mathrm{~m})$ thick (Yaman and others, 1991; Pertamina, 1996). The orientation of the bioherms is interpreted to be the result of a combination of paleogeographic features and paleocurrent directions; the separation of the two trends may have been caused by a deeper water reentrant from the east (Yaman and others, 1991). Bioherms in the northern trend are composed of skeletal-foraminiferal packstone with little coral and generally no framework whereas bioherms in the southern trend are composed of coral-algal reefs (Yaman and others, 1991). In the Jatibarang Basin area, the Parigi consists of buildups composed mostly of reef limestone that reach a thickness of approximately $490 \mathrm{ft}$ (150 m) (Adnan and others, 1991

Reservoir quality varies from tight to very good, due to cementation by calcite and development of secondary porosity (Yaman and others, 1991). Porosity is as much as 30\% and permeability 2 Darcies (Yaman and others, 1991). This reservoir has tested from 14.5 million cubic feet of gas per day (MMCFGPD) to 58.94 MMCFGPD (Pertamina, 1996). Oil is produced in wells JTB-43 and -45 (Adnan and others, 1991).

TERTIARY-PARIGI (382403) ASSESSMENT UNIT BIOGENIC GAS (38240301)

Known biogenic gas charges upper Miocene Parigi Formation carbonate reservoirs that comprise fields in the Tertiary-Parigi petroleum system (382403) (Fig. 1 and 7) (Noble and others, 1997). Other fields that have gas reserves in these reservoirs, and are distant from known mature source rocks, are included in this petroleum system although data as to the precise source of the gas are not available. Some authors have interpreted gas in the Pre-Parigi and Parigi as thermogenic, being sourced by Talang Akar coals and having migrated to the reservoir (Fig. 4) (Yaman and others, 1991), whereas Noble and others (1997) suggested that the source sediments for the near-surface bacterial gas are fine-grained claystone and mudstone facies of the Parigi and Cisubuh Formations. The gas is reported to be dry and to contain $98 \%$ methane with minor ethane, nitrogen, and carbon dioxide (Yaman and others, 1991

The upper Parigi Formation reservoir consists of platform carbonates, developed as bioherms with enhanced solution porosity, that form good reservoirs sealed by transgressive shales of the Cisubuh Formation (Yaman and others, 1991; Noble and others, 1997). These carbonates range in thickness from a few feet to as much as $400 \mathrm{ft}$ (122 m) (Yaman and others, 1997). The carbonate buildups are aligned north and south and are best developed in an east to west trend, being less well developed to the north (Yaman and others, 1997).

The Tertiary-Parigi petroleum system contributes $15 \%$ of the energy equivalent of the total gas and $8 \%$ of the total hydrocarbons to the reserves of the Northwest Java Basin province (Noble and others, 1997). Shallow targets that can be easily identified on seismic data, make this gas resource important to the total reserves of the province (Yaman and others, 1991).

TERTIARY-CENOZOIC (382404) BILLITON BASIN HYPOTHETICAL (38240401) 
This petroleum system is hypothetical and based on the presence of two basins, Vera and Billiton, in the northeastern part of the North West Java province (Fig. 1). These sedimentary basins are mapped as containing more than $6,500 \mathrm{ft}(2,000 \mathrm{~m})$ of Cenozoic sediments (Hamilton, 1974). Several wells have been drilled to basement and have encountered more than $8,200 \mathrm{ft}(2,500 \mathrm{~m})$ of sedimentary strata (Petroconsultants, 1996). Marine shelf and shoreline deposits are shown by Ponto and others (1988) to occur in the Vera and Billiton Basin areas, and probably include both source rocks and reservoir rocks similar to those of the Talang Akar Formation in the Ardjuna Basin. The basins also may contain lacustrine sediments or coals. Extrapolating from the general depositional history of the province, these strata are probably overlain by clastic fluvial, shoreline, deltaic, and marine deposits as well as carbonate platform deposits.

No possible source rock has been described but, based on maturation in other areas of the province, maturation might be expected between 3,300 - 6,600 $\mathrm{ft}(1,000$ $2,000 \mathrm{~m}$ ) of burial depth. Migration presumably could occur vertically and laterally into any clastic and carbonate reservoirs that might be present.

The Pliocene to Pleistocene Cisubuh Formation is composed of claystones that act as seals in the province. No trap style has been described. Basement highs have been encountered during drilling, suggesting that possible drape structures, stratigraphic pinchouts, or carbonate buildups are present (Petroconsultants, 1996).

\section{UNDISCOVERED PETROLEUM}

The Northwest Java Basin includes highly productive source rocks and high quality reservoir rocks trapped in numerous structural and stratigraphic settings of interest for further exploration. In the Sunda/Asri area, Wicaksono and others (1992) have modeled expelled hydrocarbons from lacustrine source rocks in the amount of almost $10 \mathrm{BBO}$. Past production combined with estimated recoverable reserves in this assessment unit total 1,330 MMBOE (Petroconsultants, 1996), and the estimated quantities of conventional oil, gas and condensate that have the potential to be added to reserves by the year 2025 are 627 MMBOE (U.S. Geological Survey World Energy Assessment Team, 2000). Faults trapping hydrocarbon that have migrated out of the mature area, similar to Widuri Field, are attractive targets. Lacustrine fans, similar to the fans that produce at Yani and Janti fields, and fluvial channel and deltaic sandstones in stratigraphic and structural traps are also possible targets. A thorough understanding of clastic deposition as it responds to rift tectonics could lead to the identification of likely prospects and it is probable that additional carbonate buildups will be discovered.

There are also numerous future exploration targets in the Ardjuna assessment unit within the Talang Akar and Upper Cibulakan sandstones. Large deltas, shoreline deposits, and sea-level highstand and lowstand features may provide additional opportunities for development of reservoirs and traps. Although most of the carbonate buildups have been identified, more subtle carbonate reservoirs and traps may yet be found. The estimated quantities of conventional oil, gas and condensate that have the potential to be added to reserves by 2025 are 1,380 MMBOE (U.S. Geological Survey World Energy Assessment Team, 2000).

\section{REFERENCES CITED}


Adnan, A., Sukowitono, and Supriyannto, 1991, Jatibarang sub basin - a half graben model in the onshore of northwest Java: Proceedings of the Twentieth Annual Convention, Indonesian Petroleum Association, v. 1, p. 279-297.

Aldrich, Jeffrey B., Rinehart, Gary P., Ridwan, Susandhi, and Schuepbach, Martin A., 1995, Paleogene basin architecture of the Sunda and Asri Basins and associated non-marine sequence stratigraphy, in Caughey, Charles A., Carter, David C., Clure, John, Gresko, Mark J., Lowry, Philip, Park, Robert K., and Wonders, Antoine, eds., International Symposium on Sequence Stratigraphy in S. E. Asia: Proceedings of the Indonesian Petroleum Association, p. 261-287.

Armon, John, Harmony, Bill, Smith, Steve, Thomas, Budiyento, Himawan, Romina, Harman, Budi, Lukito, Pujiyanto, Gilmore, Lee, Syarkawi, Ichsan, 1995, Complimentary role of seismic and well data in identifying upper Talang Akar stratigraphic sequences - Widuri Field area, Asri Basin, in Caughey, Charles A., Carter, David C., Clure, John, Gresko, Mark J., Lowry, Philip, Park, Robert K., and Wonders, Antoine, eds., International Symposium on Sequence Stratigraphy in S. E. Asia: Proceedings of the Indonesian Petroleum Association, p. 289-309.

Beach, Alastair, Brown, J. Lawson, Brockbank, Paul J., Knott, Steven D., McCallum, Jean E., and Welbon, Alastair I., 1997 Fault seal analysis of SE Asian basins with examples from West Java, in Fraser, A. J., Matthews, S. J., and Murphy, R. W., eds., Petroleum Geology of Southeast Asia: Geological Society Special Publication No. 126, p. 185-194.

Bishop, M. G., 1988, Clastic depositional processes in response to rift tectonics in the Malawi Rift, Malawi, Africa: Masters Thesis, Duke University, 122 pp.

Butterworth, P. J., Purantoro, R., and Kaldi, J. G., 1995, Sequence stratigraphic interpretations based on conventional core data: an example from the Miocene upper Cibulakan Formation, offshore Northwest Java, in Caughey, Charles A., Carter, David C., Clure, John, Gresko, Mark J., Lowry, Philip, Park, Robert K., and Wonders, Antoine, eds., International Symposium on Sequence Stratigraphy in S. E. Asia: Proceedings of the Indonesian Petroleum Association, p. 311-325.

Carter, D., and Hutabarat, M., 1994, The geometry and seismic character of mid-Late Miocene carbonate sequences, SS area, offshore northwest Java: Proceedings of the Twenty Third Annual Convention Indonesian Petroleum Association, v.1, p. 323-338.

Cole, J. M., and Crittenden, S., 1997, Early tertiary basin formation and the development of lacustrine and quasi-lacustrine/marine source rocks on the Sunda Shelf of SE Asia, in Fraser, A. J., Matthews, S. J., and Murphy, R. W., eds., Petroleum Geology of Southeast Asia: Geological Society Special Publication No. 126, p. 147-183.

Courteney, S., Cockcroft, P., Miller, R., Phoa, R. S. K., and Wight, A. W. R., eds., 1989, Indonesia Oil and Gas Fields Atlas Volume IV: Java: IPA Professional Division Oil and Gas Fields Atlas Sub-Committee, 249 pp., 2 maps.

Doust, Harry, Lijmbach, Gerard, 1997, Charge constraints on the hydrocarbon habitat and development of hydrocarbon systems in Southeast Asia Tertiary basins, in Howes, J. V. C., and Noble, R. A., eds., Proceedings of an International Conference on Petroleum Systems of SE Asia \& Australasia: Indonesian Petroleum Association, 
p. $115-125$.

Gordon, T. L., 1985, Talang Akar coals-Ardjuna subbasin oil source: Proceedings of the Fourteenth Annual Convention Indonesian Petroleum Association, v. 2, p. 91120.

Gresko, M., Suria, C., and Sinclair, S., 1995, Basin evolution of the Ardjuna rift system and its implications for hydrocarbon exploration, offshore Northwest Java, Indonesia: Proceedings of the Twenty Fourth Annual Convention Indonesian Petroleum Association, v. , p. 147-161.

Hall, Robert, 1997a, Cenozoic tectonics of SE Asia and Australasia, in Howes, J. V. C., and Noble, R. A., eds., Proceedings of an International Conference on Petroleum Systems of SE Asia \& Australasia: Indonesian Petroleum Association, p. 47-62.

Hall, Robert, 1997b, Cenozoic plate tectonic reconstructions of SE Asia, in Fraser, A. J., Matthews, S. J., and Murphy, R. W., eds., Petroleum Geology of Southeast Asia: Geological Society Special Publication No. 126, p. 11-23.

Hamilton, Warren, 1974, Map of Sedimentary Basins of the Indonesian Region: USGS MAP 1-875-B.

Hamilton, Warren, 1979, Tectonics of the Indonesian Region: USGS Professional Paper 1078, 345 pp., 1 map.

Haposan, N., Mitterer, Richard M., and Morelos-Garcia, J. A., 1997, Differentiation of oils from the NW Java Basin into three oil types based on biomarker composition, in Howes, J. V. C., and Noble, R. A., eds., Proceedings of an International Conference on Petroleum Systems of SE Asia \& Australasia: Indonesian Petroleum Association, p. 667-679.

Howes, J. V. C., 1997, Petroleum resources and petroleum systems of SE Asia, Australia, Papua New Guinea, and New Zealand, in Howes, J. V. C., and Noble, R. A., eds., Proceedings of an International Conference on Petroleum Systems of SE Asia \& Australasia: Indonesian Petroleum Association, p. 81-100.

IPA Professional Division, 1989, Courteney, S., Cockcroft, P., Miller, R., Phoa, R. S. K., and Wight, A. W. R., eds., Indonesian Oil and Gas Fields Atlas Volume IV: Java: Indonesian Petroleum Association, 340 p., 2 maps.

Kalan, T., Sitorus, H. P., and Eman, M., 1994, Jatibarang Field, geologic study of volcanic reservoir for horizontal well proposal: Proceedings of the Twenty Third Annual Convention Indonesian Petroleum Association, v.1, p. 229-243.

Kaldi, J. G., and Atkinson, C. D., 1993, Seal potential of the Talang Akar Formation, BZZ area, offshore NW Java, Indonesia: Proceedings of the Twenty Second Annual Convention Indonesian Petroleum Association, v.1, p. 373-393.

Katz, B. J., 1991, Controls on lacustrine source rock development: a model for Indonesia: Proceedings of the Twentieth Annual Convention Indonesian Petroleum Association, v.1, p. 587-619.

Katz, B. J., Royle, R. A., and Mertani, B., 1990, Southeast Asian and southwest Pacific coals contribution to the petroleum resource base: Proceedings of the Nineteenth Annual Convention Indonesian Petroleum Association, v.1, p. 299-

Keetley, J. T., Cooper, G. T., Hill, K. C., Kusumabrata, Y., O’Sullivan, P. B., and Saefudin, I., 1997, The structural development of the Honje High, Bayah High and adjacent offshore areas, West Java, Indonesia, in Howes, J. V. C., and Noble, R. A., eds., Proceedings of an International Conference on Petroleum Systems of 
SE Asia \& Australasia: Indonesian Petroleum Association, p. 655-665.

Kingston, John, 1988, Undiscovered Petroleum Resources of Indonesia: USGS OpenFile report 88-379, $217 \mathrm{pp}$.

Koesoemadinata, R. P., and Siregar, S., 1984, Reef facies model of the Rajamandala Formation, west Java: Proceedings of the Thirteenth Annual Convention Indonesian Petroleum Association, v. 1, p. 1-18.

Lambiase, J. J., 1990, A model for tectonic control of lacustrine stratigraphic sequences in continental rift basins: AAPG Memoir 50, p. 265-276.

Lambiase, J. J., and Bosworth, W., 1995, Structural controls on sedimentation in continental rifts: Geological Society Special Publication 80, p. 117-144.

Longley, Ian, M., 1997, The tectonostratigraphic evolution of SE Asia, in Fraser, A. J., Matthews, S. J., and Murphy, R. W., eds., Petroleum Geology of Southeast Asia: Geological Society Special Publication No. 126, p. 311-339.

Longman, M. W., 1993, Southeast Asian Tertiary Carbonate Reservoirs; Volume 1, Lithologies \& Environments Controls on Deposition Basin Studies: Petroconsultants.

Meissner, F. F., 1997, The role of depositional sequences in creating and controlling petroleum systems--basic principles and examples, in Howes, J. V. C., and Noble, R. A., eds., Proceedings of an International Conference on Petroleum Systems of SE Asia \& Australasia: Indonesian Petroleum Association, p. 37-45.

Molina, Jorge, 1985, Petroleum geochemistry of the Sunda Basin: Proceedings of the Fourteenth Annual Convention Indonesian Petroleum Association, v. 2, p. 143179.

Noble, Ron A., Pratomo, Kakung H., Nugrahanto, Kuntadi, Ibrahim, Anditya, M. T., Praseetya, Indra, Mujahidin, Nizar, Wu, C. H., and Howes, J. V. C., 1997, Petroleum systems of Northwest Java, Indonesia, in Howes, J. V. C., and Noble, R. A., eds., Proceedings of an International Conference on Petroleum Systems of SE Asia \& Australasia: Indonesian Petroleum Association, p. 585-600.

Nugrahanto, Kuntadi, and Noble, R. A., 1997, Structural control on source rock development and thermal maturity in the Ardjuna Basin, offshore northwest Java, Indonesia, in Howes, J. V. C., and Noble, R. A., eds., Proceedings of an International Conference on Petroleum Systems of SE Asia \& Australasia: Indonesian Petroleum Association, p. 631-653.

Nutt, W. L., and Sirait, J., 1985, Application of offset seismic profiles in the Jatibarang volcanic reservoir: Proceedings of the Fourteenth Annual Convention Indonesian Petroleum Association, v. 2, p. 385-398.

Park, Robert K., Matter, Albert, and Tonkin, Paul C., 1995, Porosity evolution in the Batu Raja carbonates of the Sunda Basin - windows of opportunity: Proceedings of the Twenty Fourth Annual Convention Indonesian Petroleum Association, v. 1, p.163-176.

Pertamina BPPKA, 1996, Petroleum Geology of Indonesian Basins; Principles, Methods and Application, Volume III, West Java Sea Basins.

Petroconsultants, 1996, Petroleum Exploration and Production Database: Petroconsultants, Inc., P.O. Box 740619, 6600 Sands Point Drive, Houston TX 77274-0619, USA or Petroconsultants, Inc., P.O. Box 152, 24 Chemin de la Mairie, 1258 Perly, Geneva, Switzerland. 
Ponto, C. V., Wu, C. H., Pranoto, A., and Stinson, W. H., 1988, Improved interpretation of the Talang Akar depositional environment as an aid to hydrocarbon exploration in the ARII Offshore Northwest Java contract area: Proceedings of the Seventeenth Annual Convention Indonesian Petroleum Association, v. 1, p. 397422.

Pramono, H., Wu, C. H., Noble, R. A., 1990, A new oil kitchen and petroleum bearing subbasin in the offshore northwest Java area: Proceedings of the Nineteeenth Annual Convention Indonesian Petroleum Association, v.1, p. 253-278.

Pulunggono, A., 1985, The changing pattern of ideas on Sundaland within the last hundred years, its implications to oil exploration: Proceedings of the Fourteenth Annual Convention Indonesian Petroleum Association, v. 2, p. 385-398.

Purantoro, R., Butterworth, P. J., Kaldi, J. G., and Atkinson, C. D., 1994, A sequence stratigraphic model of the upper Cibulakan sandstones (Main interval), offshore northwest Java basin: insights from U-11 well: Proceedings of the Twenty Third Annual Convention Indonesian Petroleum Association, v. 1, p. 289-306.

Reksalegora, S. W., Kusumanegara, Y., and Lowry, P., 1996, A depositional model for the "Main" interval, Upper Cibulakan Formation: its implications for reservoir distribution and prediction, ARII ONWJ: Proceedings of the Twenty-Fifth Silver Anniversary Convention Indonesian Petroleum Association, v. 1, p. 163-173.

Reminton, C. H., and Pranyoto, U., 1985, A hydrocarbon generation analysis in Northwest Java Basin using Lopatin's method: Proceedings of the Fourteenth Annual Convention Indonesian Petroleum Association, v. 2, p. 122-141.

Schiefelbein, Craig, and Cameron, Nick, 1997, Sumatra/Java oil families, in Fraser, A. J., Matthews, S. J., and Murphy, R. W., eds., Petroleum Geology of Southeast Asia: Geological Society Special Publication No. 126, p. 143-146.

Schiefelbein, C. F., Zumberge, J. E., and Brown, S. W., 1997, Petroleum systems in the Far East, in Howes, J. V. C., and Noble, R. A., eds., Proceedings of an International Conference on Petroleum Systems of SE Asia \& Australasia: Indonesian Petroleum Association, p. 101-113.

Sladen, Chris, 1997, Exploring the lake basin of east and southeast Asia, in Fraser, A. J., Matthews, S. J., and Murphy, R. W., eds., Petroleum Geology of Southeast Asia: Geological Society Special Publication No. 126, p. 49-76.

Soenandar, Hardjo Basuki, 1997, Thermal history of the western Indonesian basins (Sunda-Asri, Northwest Java, and Southwest Java): evidence from fission track geochronology of apatite, in Howes, J. V. C., and Noble, R. A., eds., Proceedings of an International Conference on Petroleum Systems of SE Asia \& Australasia: Indonesian Petroleum Association, p. 601-629.

Soulisa, B., and Sujanto, F. X., 1979, Hydrocarbonoccurrences in the KandanghaurCemara area, North West Java: Proceedings of the Eight Annual Convention Indonesian Petroleum Association, p.223-245.

Sudarmono, Suherman, T., and Eza, B, 1997, Paleogene basin development in Sundaland and it's role to the petroleum systems in western Indonesia, in Howes, J. V. C., and Noble, R. A., eds., Proceedings of an International Conference on Petroleum Systems of SE Asia \& Australasia: Indonesian Petroleum Association, p. 545600.

Suria, C., 1991, Development strategy in the BZZ Field and the importance of detailed 
depositional model studies in the reservoir characterization of Talang Akar channel sandstones: Proceedings of the Twentieth Annual Convention Indonesian Petroleum Association, v.1, p. 419-451.

Suria, C., Atkinson, C. D., Sinclair, S. W., Gresko, M. J., and Mahaperdana, B., 1994, Application of integrated sequence stratigraphic techniques in nonmarine/marginal marine sediments; and example from the upper Talang Akar Formation, offshore northwest Java: Proceedings of the Twenty Third Annual Convention Indonesian Petroleum Association, v.1, p. 146-159.

Thompson, S., Arpandi, D., and Sujanto, X., 1979, Thermal maturity and oil generation with reference to the CMS-1 (Java) and SUSU Selatan-1 (Sumatra) wells, Indonesia: Proceedings of the Eight Annual Convention Indonesian Petroleu Association, p.385-405.

Todd, S. P., Dunn, M. E., and Barwise, A. J. G., 1997, Characterizsing petroleum charge systems in the tertiary of SE Asia, in Fraser, A. J., Matthews, S. J., and Murphy, R. W., eds., Petroleum Geology of Southeast Asia: Geological Society Special Publication No. 126, p. 25-47.

U.S. Geological Survey World Energy Assessment Team, 2000, U.S. Geological Survey World Petroleum Assessment 2000—Description and Results: USGS Digital Data Series DDS-60, version 1.1, multi disc set, four CD-ROMs.

van Bemmelen, R. W., 1949, The Geology of Indonesia, Volume II Economic Geology: The Hague, 265 pp.

Wicaksono, P., Wight, A. W. R., Lodwick, W. R., Netherwood, R. E., Budiarto, B., and Hanggoro, D., 1995, Use of sequence stratigraphy in carbonate exploration: Sunda Basin, Java Sea, Indonesia, in Caughey, Charles A., Carter, David C., Clure, John, Gresko, Mark J., Lowry, Philip, Park, Robert K., and Wonders, Antoine, eds., International Symposium on Sequence Stratigraphy in S. E. Asia: Proceedings of the Indonesian Petroleum Association, p. 197-229.

Wicaksono, P., Armon, J. W., and Haryono, S., 1992, The implications of basin modelling for exploration - Sunda Basin case study, offshore southeast Sumatra: Proceedings of the Twenty First Annual Convention Indonesian Petroleum Association, v.1, p. 379-415.

Wight, Andrew and Hardian, Daniel, 1982, Importance of diagenesis in carbonate exploration and production, lower Batu Raja carbonates, Krisna Field, Java Sea: Proceedings of the Eleventh Annual Convention Indonesian Petroleum Association, v. 1, p. 211-235.

Wight, A., Friestad, H., Anderson, I., Wicaksono, P., and Reminton, C. H., 1997, Exploration history of the offshore Southeast Sumatra PSC, Java Sea, Indonesia, in Fraser, A. J., Matthews, S. J., and Murphy, R. W., eds., Petroleum Geology of Southeast Asia: Geological Society Special Publication No. 126, p. 121-142.

Yaman, F., Ambismar, T., Budhari, T., 1991, Gas exploration in Parigi and pre-Parigi carbonate buildups, NW Java Sea: Proceedings of the Twentieth Annual Convention Indonesian Petroleum Association, v.1, p. 319-346.

Young, R., Harmony, W. E., Juniarto, G., and Thomas, B., 1991, Widuri Field, offshore southeast Sumatra: sandbody geometries and the reservoir model: Proceedings of the Twentieth Annual Convention Indonesian Petroleum Association, v.1, p. 385-417. 


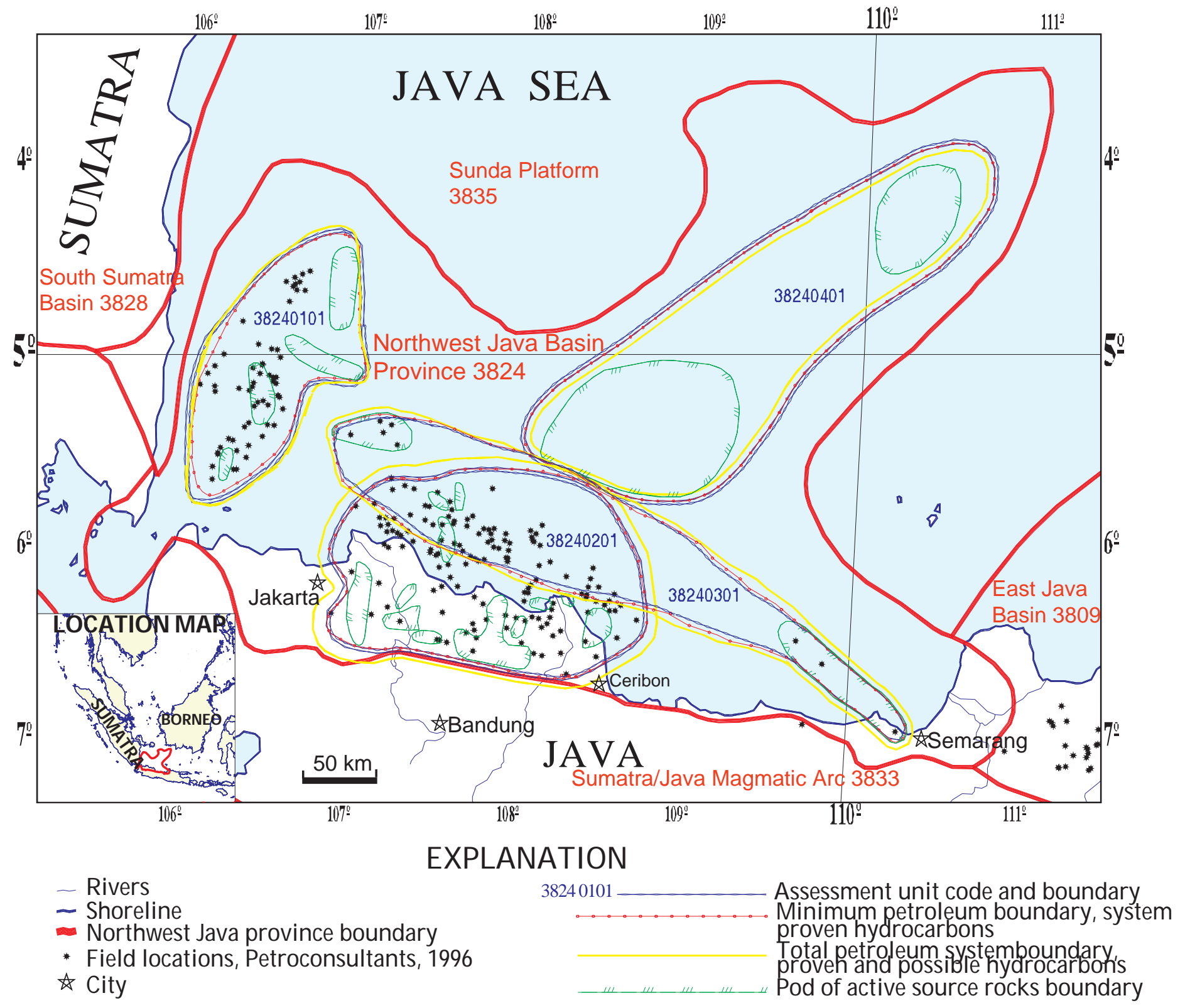

Figure 1. Index map of Northwest J ava Basin Province, Indoresia (3824). Four petroleum systems are shown. The Banuwati-Oligocene/Miocene petroleumsystem (382401) consists of lacustrine Banuwati Formation source rock and contains one assessment unit, Sunda/Asri (38240101). The J atibarang/Talang Akar-Oligocene/Miocene petroleum system (382402) consists of lacustrine and coal source rocks of the Jatibarang and Talang Akar Formations and contains one assessment unit, Ardjuna (38240201). The emaining petroleum systems are the Tertiary-Parigi (382403), Biogenic Gas assessment unit (38240301); and the Tertiary-Cenozoic (382404), Billiton Basin hypothetical assessment unit (38240401). 


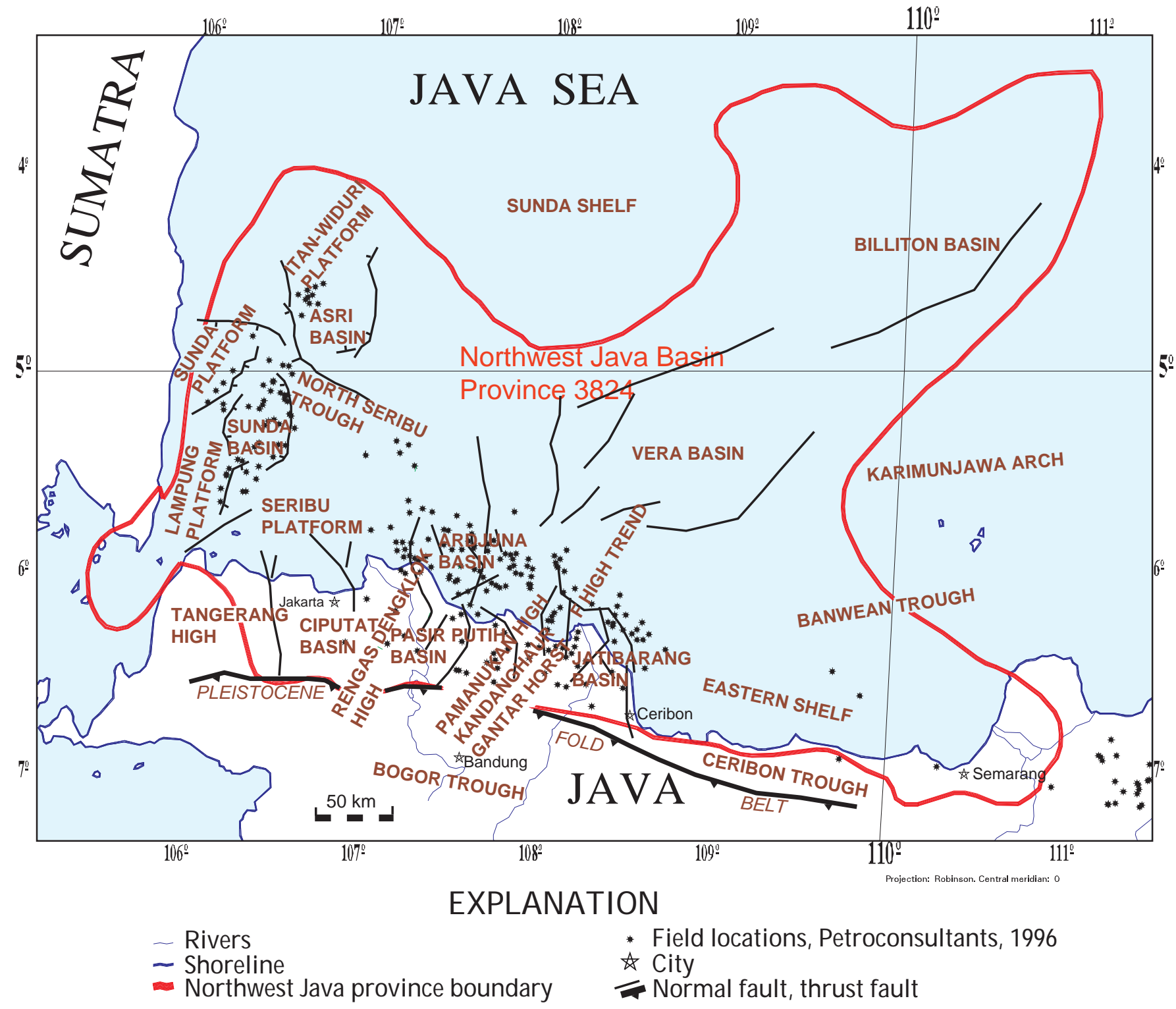

Figure 2. Northwest J ava Basin Province, Indonesia (3824) \$howing major structural features (Reminton and Pranyoto, 1985; Adnan and others, 199). 


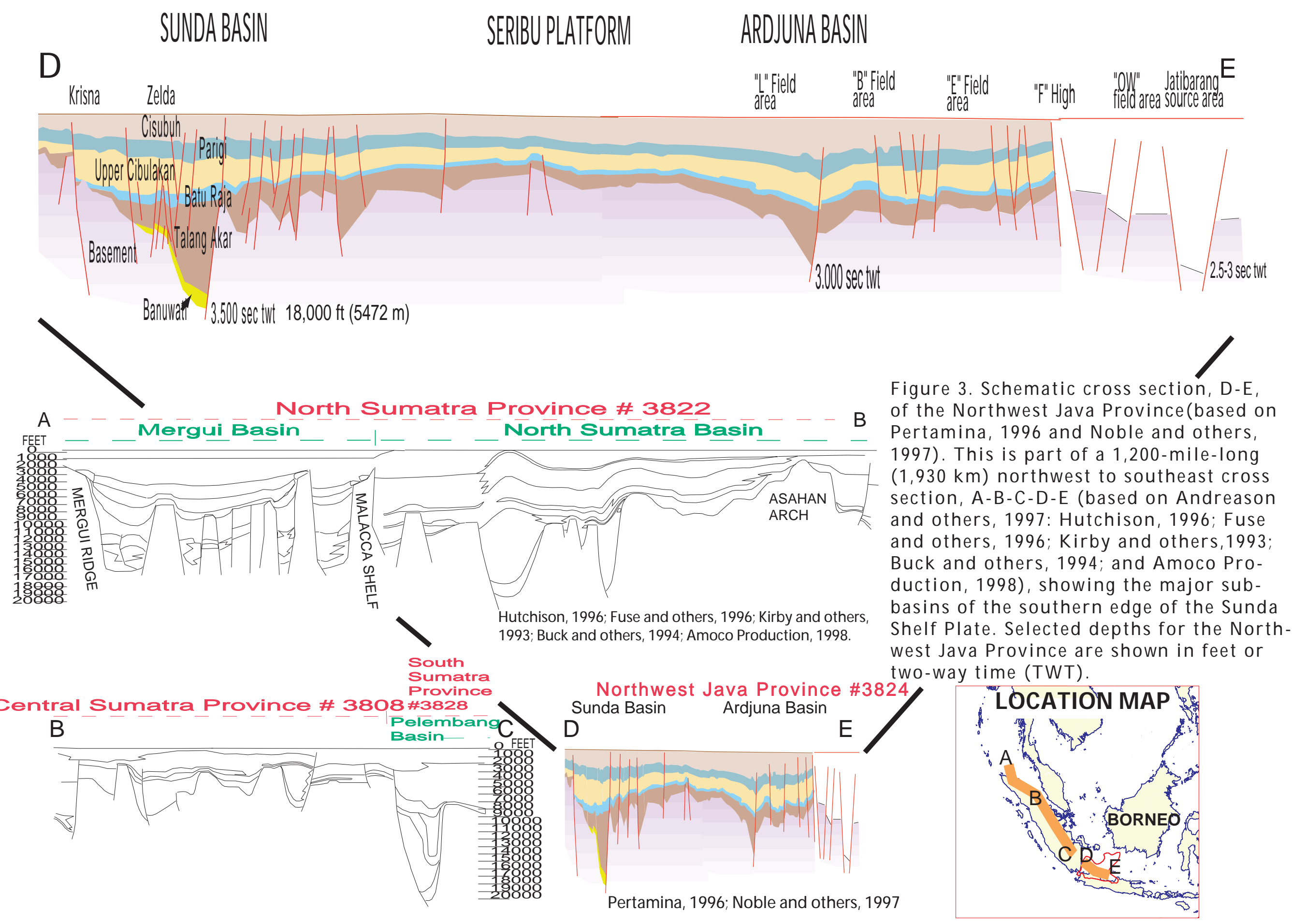




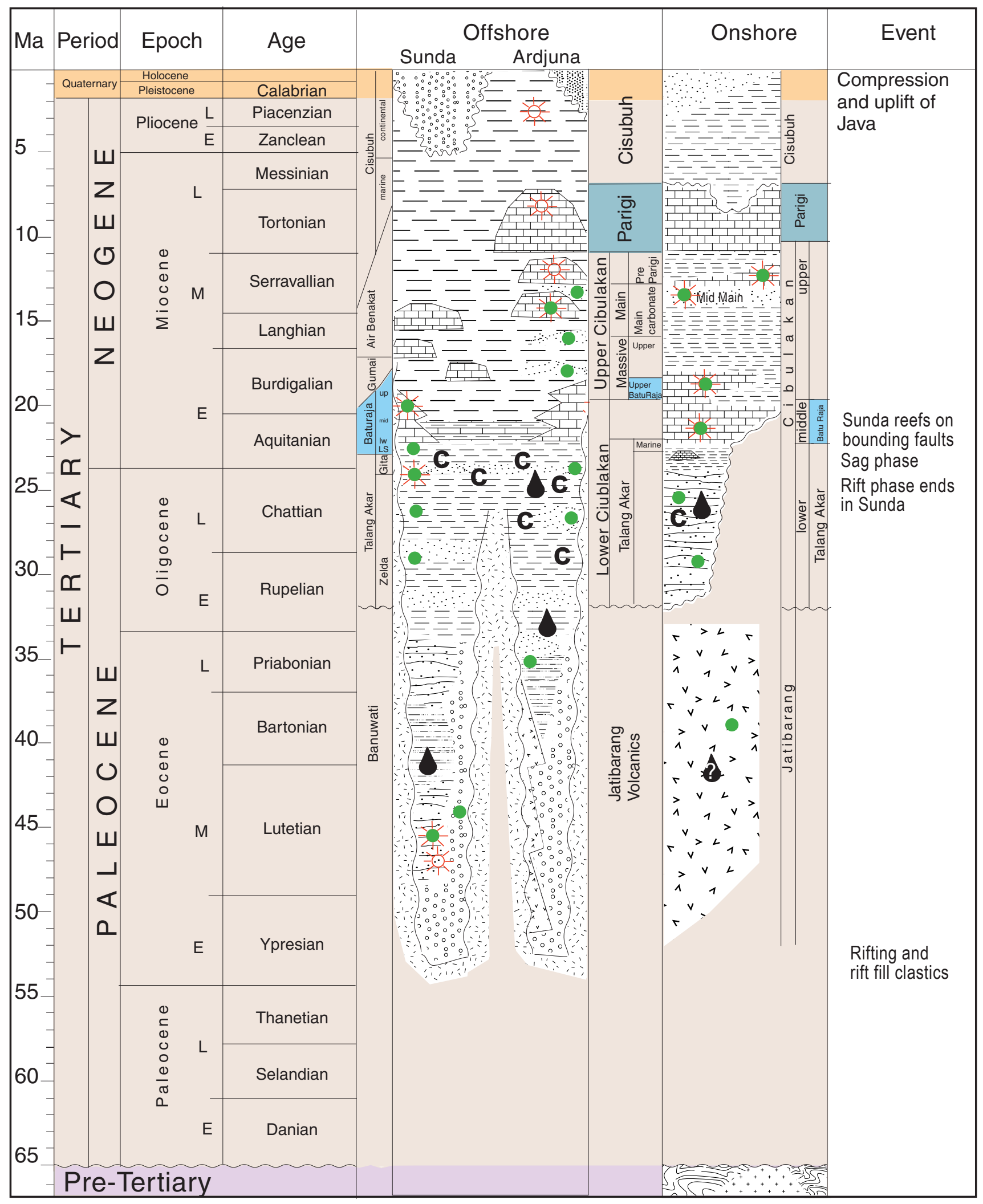

Figure 4. Generalized stratigraphic columns for the Sunda/Asri area, the offshore Ardjuna area, and the onshore Ardjuna area. Noble and others (1997) date the base of the Jatibarang/Banuwati at $45 \mathrm{Ma}$, the base of the Talang Akar at $37 \mathrm{Ma}$, the base of the Baturaja at $24 \mathrm{Ma}$, and the base of the Upper Cibulakan at approximately $20 \mathrm{Ma}$. Pertamina (1996) dates the Jatibarang from 60-34 Ma with the unconformity at $34 \mathrm{Ma}$. Gas 棌, oil •, oil/gas rock intervals $\triangle$, coal c. Gordon, 1985; Wickasono and others, 1992; Kalan and others, 1994; Pertamina, 1996. 


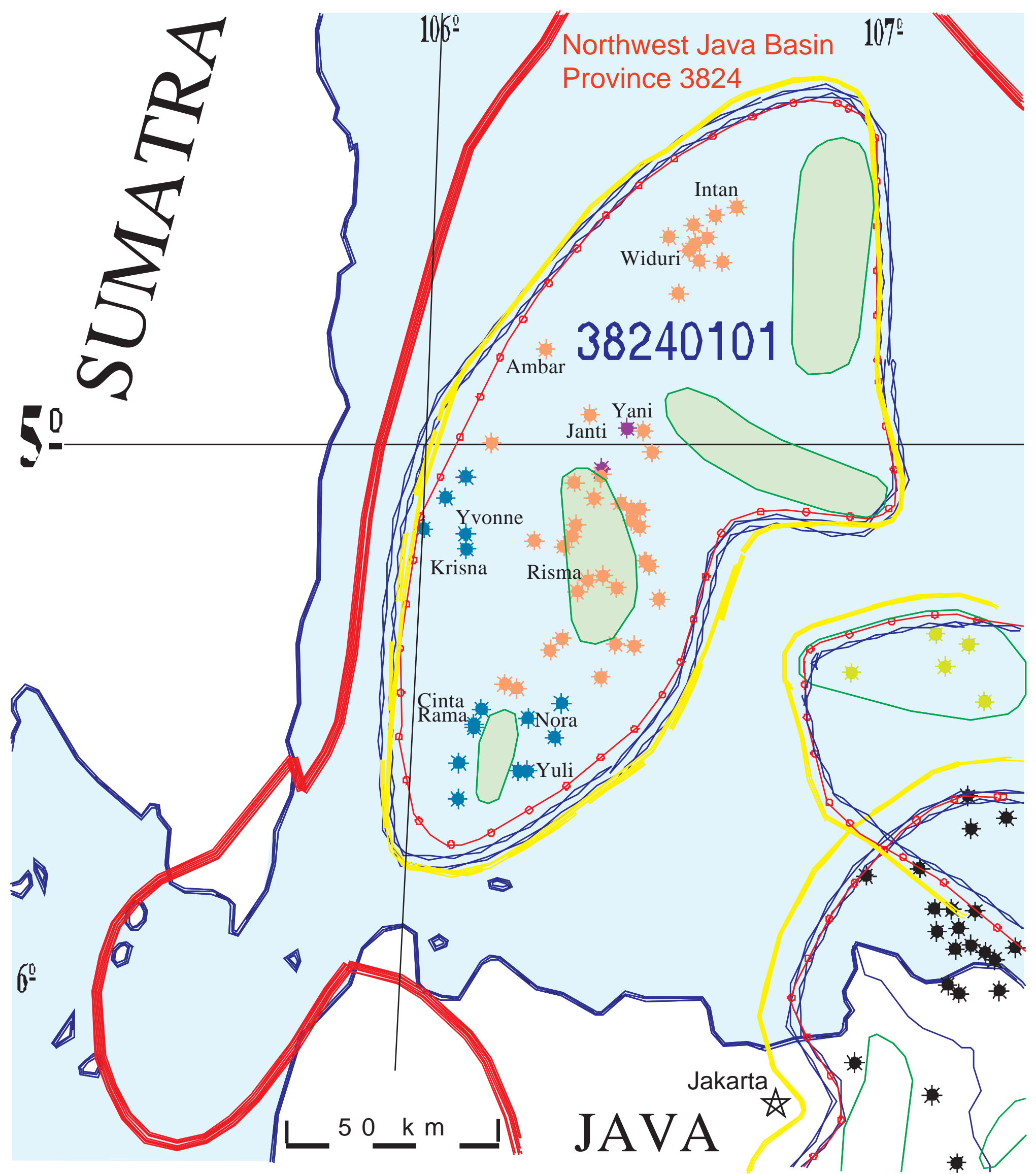

* Field location with Talang Akar sandstone reservoir * Field location with Batu Raja limestone reservoir * Field location with Banuwati sandstone reservoir * Field location with Pre-Parigi limestone reservoir * Field location with Parigi limestone reservoir

\section{EXPLANATION}

- Rivers.

- Shoredine

* Field locations, Petroconsultants, 1996

$\star$ City
38240101

996
Assessment unit code and boundary Minimum petroleum system boundary, proven hydrocarbons Total petroleum, bystem, boundary, Pod of active source rocks boundary

Figure 5. Index map showing the Banuwati-Oligocene,Miocene petroleum system (382401) containing one assessment unit, Sunda/Asri (38240101). Generalized pods of active source rock are shown in green. Major hydrocarbon reservoirs of each area shown (Petroconsultants, 1996). 


\section{Northwest Java Province 3824 Oils}

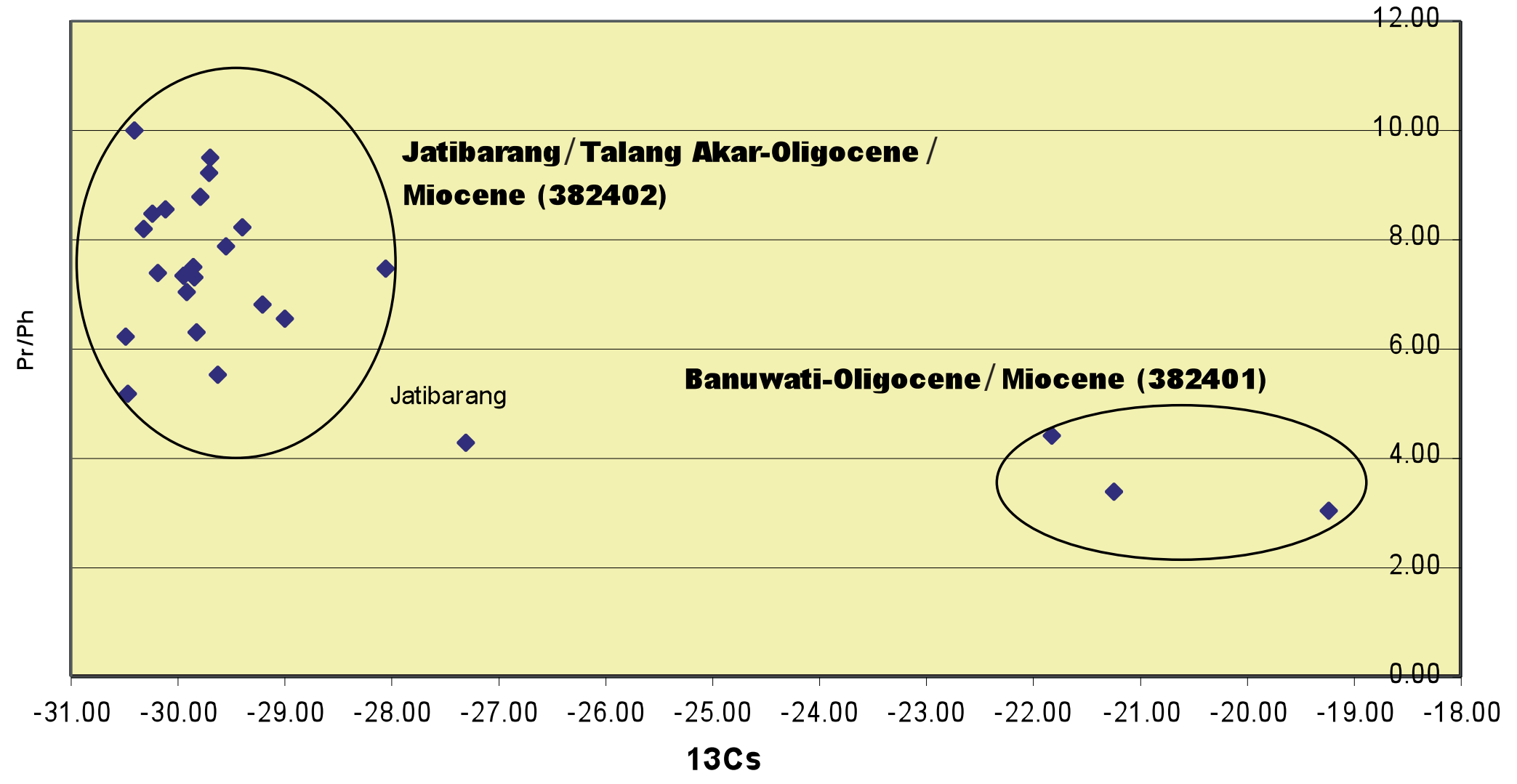

Figure 6. Graph of stable carbon isotope composition of thesaturate hydrocarbon fraction (13Cs) plotted against the pristine to phytane ratio (Pr/Ph) of oils in the Northwest J ava Province, 3824. Two distinct groups resultconfirming interpretations of different source rocks for the two petroleum systems. Petroleum system 382401 is attributed to lacustrine shale source rocks and 362402 is attributed to coal and coaly shale source rocks. Source data used with permission of GeoMark Research, Inc., from Oil Information Library System, 1998. 


\begin{tabular}{|l|l|l|l|l|l|l|}
\hline \multicolumn{2}{|c|}{} & & & \\
\hline
\end{tabular}

BANUWATI-OLIGOCENE/ MIOCENE 382401

JATIBARANG/ TALANG AKAR-OLIGOCENE/ MIOCENE 382402

TERTIARY-PARIGI 382403

Figure 7. Events chart showing the three major petroleum systems of the Northwest J ava Province, 3824. The fourth petroleum system, 382404 Tertiary-Cenozoic is hypothetical and is not known to contain hydrocarbons. 


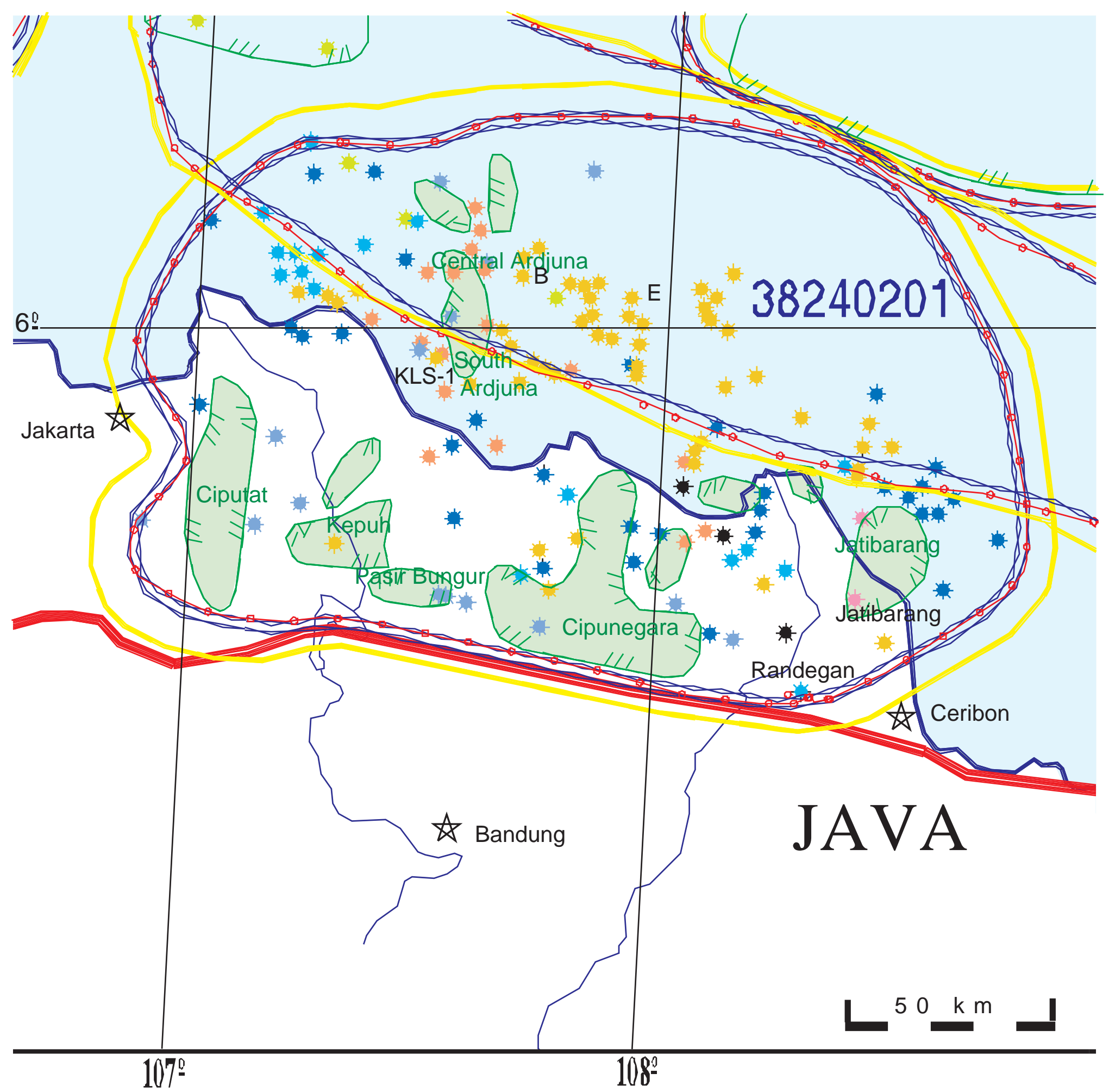

\section{EXPLANATION}

Field locations with Parigi limestone reservoir

Field locations with Pre-Parigi limestone reservoir

Field locations with Main limestone reservoir

Field locations with Main and Massivesandstone

Field locations with Batu Raja limestone reservoir

Field locations with Talang Akar sandstone reservoir

Field locations with Jatibrang tuff reservoir
Rivers

Shoreline

Northwest Java province boundary

* Field locations, Petroconsultants, 1996

$\notin$ City
Assessment unit code and boundary Minimum petroleum system boundary, proven hydrocarbons Total petrol eum system boundary Pod of activesource rocks boundary

Figure 8. Northwest J ava Basin Province, Indonesia (3824) \$owing the Jatibarang/Talang AkarOligocene/Miocene petroleum system and the Ardjuna assessment unit (38240201). Pods of active source rock are shown in green along with fields as defined by Petroconsultants (1996) and other important discoveries or wells. Major hydrocarbon reservoirs are shown (Petroconsultants, 1996). From Noble and others, 1997. 